Post-Closure Inspection, Sampling, and Maintenance Report for the Salmon, Mississippi, Site Calendar Year 2011

March 2012

Approved for public release; further dissemination unlimited

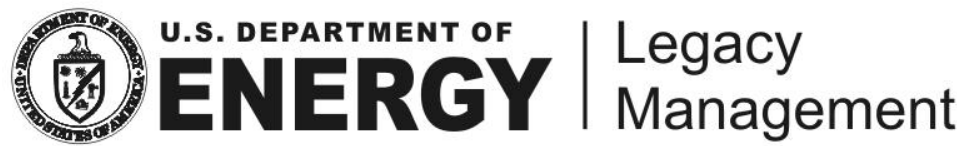


Available for sale to the public from:

\author{
U.S. Department of Commerce \\ National Technical Information Service \\ 5301 Shawnee Road \\ Alexandria, VA 22312 \\ Telephone: 800.553 .6847 \\ Fax: 703.605.6900 \\ E-mail: orders@ntis.gov \\ Online Ordering: http://www.ntis.gov/help/ordermethods.aspx
}

Available for a processing fee to U.S. Department of Energy and its contractors, in paper, from:

\author{
U.S. Department of Energy \\ Office of Scientific and Technical Information \\ P.O. Box 62 \\ Oak Ridge, TN 37831-0062 \\ Phone: 865.576 .8401 \\ Fax: 865.576 .5728 \\ Email: reports@adonis.osti.gov
}

Reference herein to any specific commercial product, process, or service by trade name, trademark, manufacturer, or otherwise, does not necessarily constitute or imply its endorsement, recommendation, or favoring by the United States Government or any agency thereof or its contractors or subcontractors. 


\section{Post-Closure Inspection, Sampling, and Maintenance Report for the Salmon, Mississippi, Site Calendar Year 2011}

March 2012 
This page intentionally left blank 


\section{Contents}

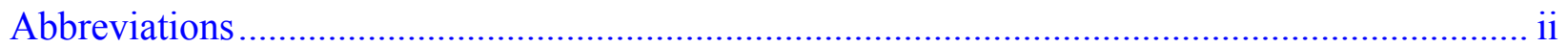

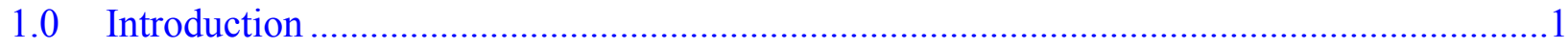

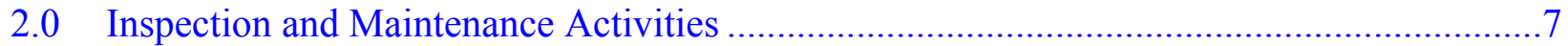

2.1 Institutional, Engineering, and Physical Controls ..................................................

2.1.1 Deed restrictions and Ground Zero Monument ..........................................7

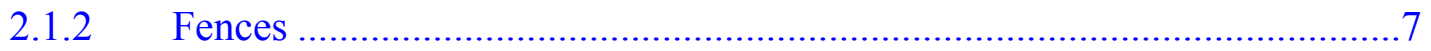

2.1.3 Gates and Locks .............................................................................

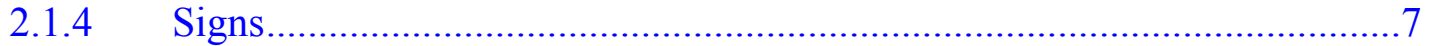

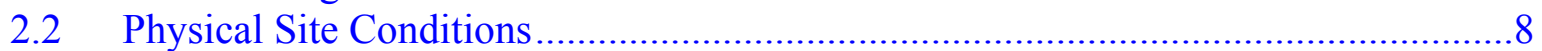

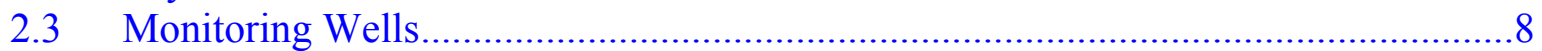

$2.4 \quad$ Site Ecology Conditions ................................................................................11

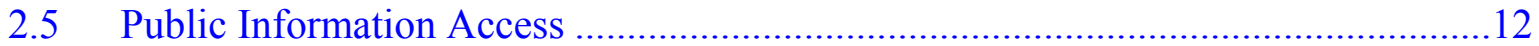

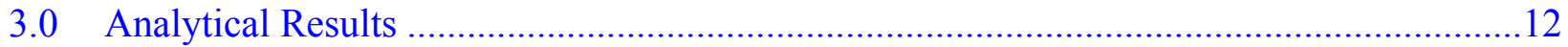

3.1 2011 Sample Results Greater than Standards...................................................13

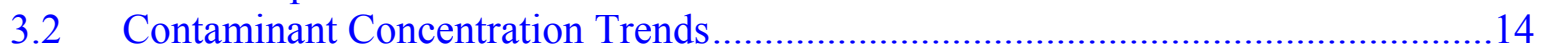

3.3 2011 Water-Level Measurements.......................................................................14

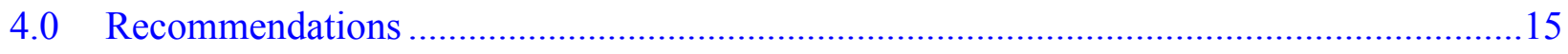

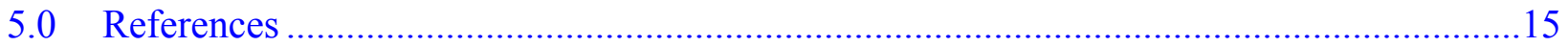

\section{Figures}

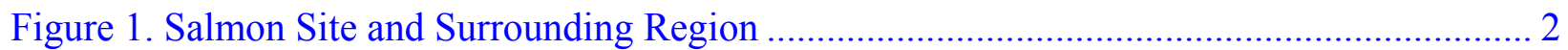

Figure 2. Sampling Locations within the Salmon Site ………................................................... 3

Figure 3. Topographic Map of the Salmon Site with Road Features............................................... 9

\section{Tables}

Table 1. Contaminants of Concern Detected Above the MCL or TRG Since 2004..................... 5

Table 2. Long-Term Surveillance and Maintenance Objectives for the Salmon,

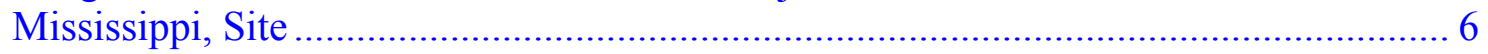

Table 3. 2011 Analytical Results of Groundwater Exceeding the MCL or TRG........................ 13

\section{Appendixes}

Appendix A Selected 2011 Images

Appendix B 2011 Laboratory Analytical Results

Appendix C Concentration Trend Plots

Appendix D 2011 Water-Level Elevations 


\section{Abbreviations}

AEC U.S. Atomic Energy Commission

DOE U.S. Department of Energy

EPA U.S. Environmental Protection Agency

$\mathrm{ft}$ feet (foot)

LM Office of Legacy Management

MCL maximum contaminant level set by the U.S. Environmental Protection Agency

MDC minimum detectable concentration

pCi/L picocuries per liter of water (about $1 / 27$ radioactive disintegrations per second per liter)

TCE trichloroethene

TRG target remediation goal set by the State of Mississippi

VOC volatile organic compound 


\subsection{Introduction}

This report summarizes the 2011 annual inspection, sampling, measurement, and maintenance activities performed at the Salmon, Mississippi, Site (Salmon site ${ }^{1}$ ). The draft Long-Term Surveillance and Maintenance Plan for the Salmon Site, Lamar County, Mississippi (DOE 2007) specifies the submittal of an annual report of site activities with the results of sample analyses.

The Salmon site consists of 1,470 acres. The site is located in Lamar County, Mississippi, approximately 10 miles west of Purvis, Mississippi, and about 21 miles southwest of Hattiesburg, Mississippi (Figure 1).

The State of Mississippi owns the surface real estate subject to certain restrictions related to subsurface penetration. The State is the surface operator (with its agent, the Mississippi Forestry Commission). The federal government owns the subsurface real estate (including minerals) and some surface features ${ }^{2}$, shares right-of-entry easements with the State, and retains rights related to subsurface monitoring. The U.S. Department of Energy (DOE) Office of Legacy Management (LM), a successor agency to the U.S. Atomic Energy Commission (AEC), is responsible for the long-term surveillance and maintenance of the subsurface real estate.

The AEC conducted Projects Dribble and Miracle Plan to study seismic signatures from explosions in the Tatum Salt Dome beneath the site. Figure 2 shows an outline of the salt dome at about 2,500 feet (ft) below the surface. Two nuclear tests (code name Dribble) and two chemical-explosive tests (code name Miracle Plan) were conducted well within the Tatum Salt Dome between 1964 and 1970. The first nuclear test_-Salmon (in 1964) — created a cavity $2,710 \mathrm{ft}$ below ground surface. The second test_-Sterling (in 1966) — and the two subsequent chemical detonations, Diode Tube (1969) and Humid Water (1970), were conducted within the cavity created by the Salmon test. No radioactivity was released to the surface during the four tests. Residual radioactivity from Project Dribble is contained within the walls and the cavity itself. The properties of the salt - plasticity and impermeability - provide geologic isolation from the surroundings.

The site was cleaned up and decommissioned in 1972. During the cleanup, most of the soil and drilling mud contamination from drill-back operations were slurried and injected into the cavity. All test boreholes for emplacement, drill back, and injection were plugged and abandoned in accordance with the requirements of the State of Mississippi.

\footnotetext{
${ }^{1}$ The Salmon site is locally known as the Tatum Salt Dome Test Site.

${ }^{2}$ The groundwater monitoring wells, the protective bollards and concrete pads around each well, three survey bench marks, and the monument at ground zero.
} 


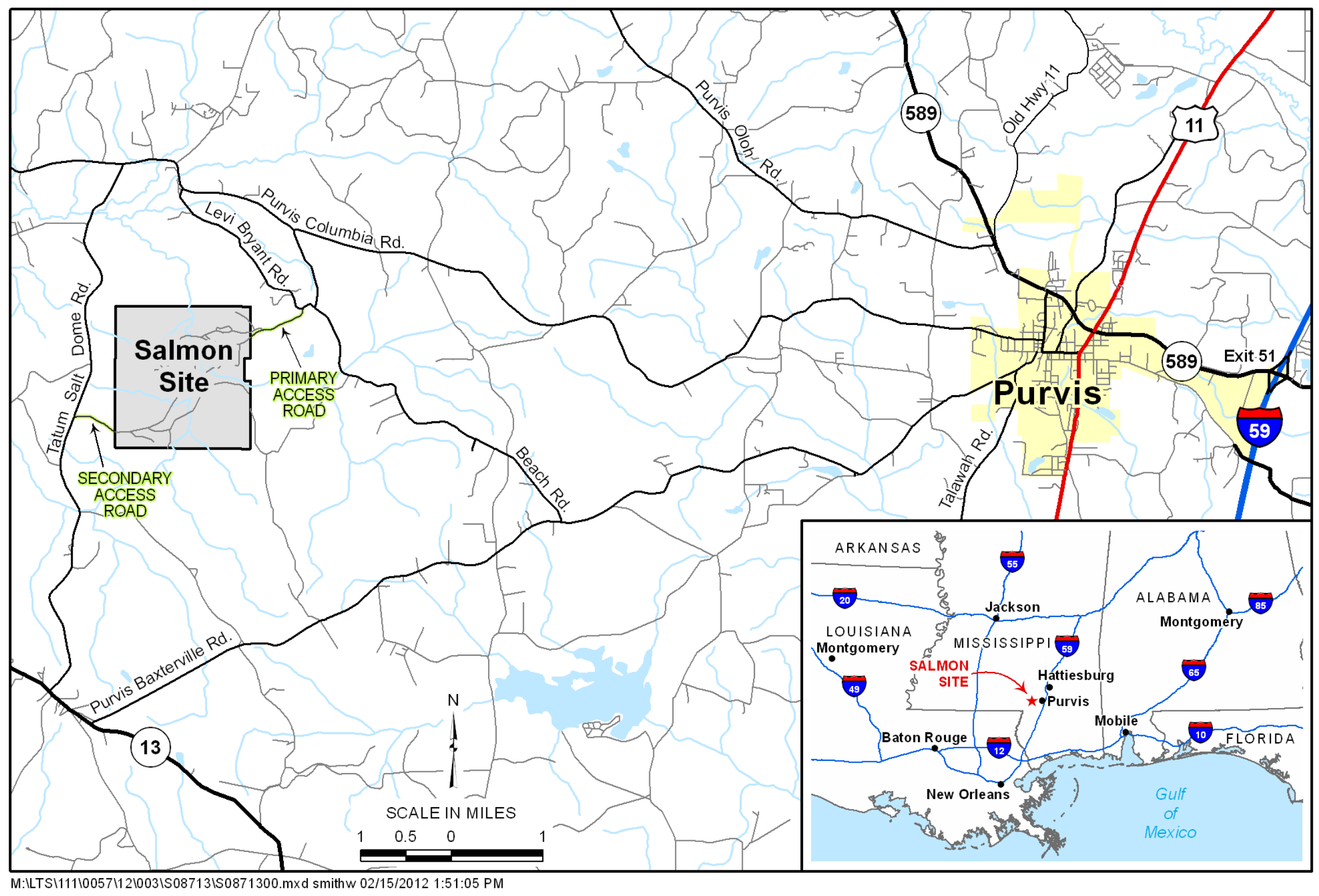

Figure 1. Salmon Site and Surrounding Region 


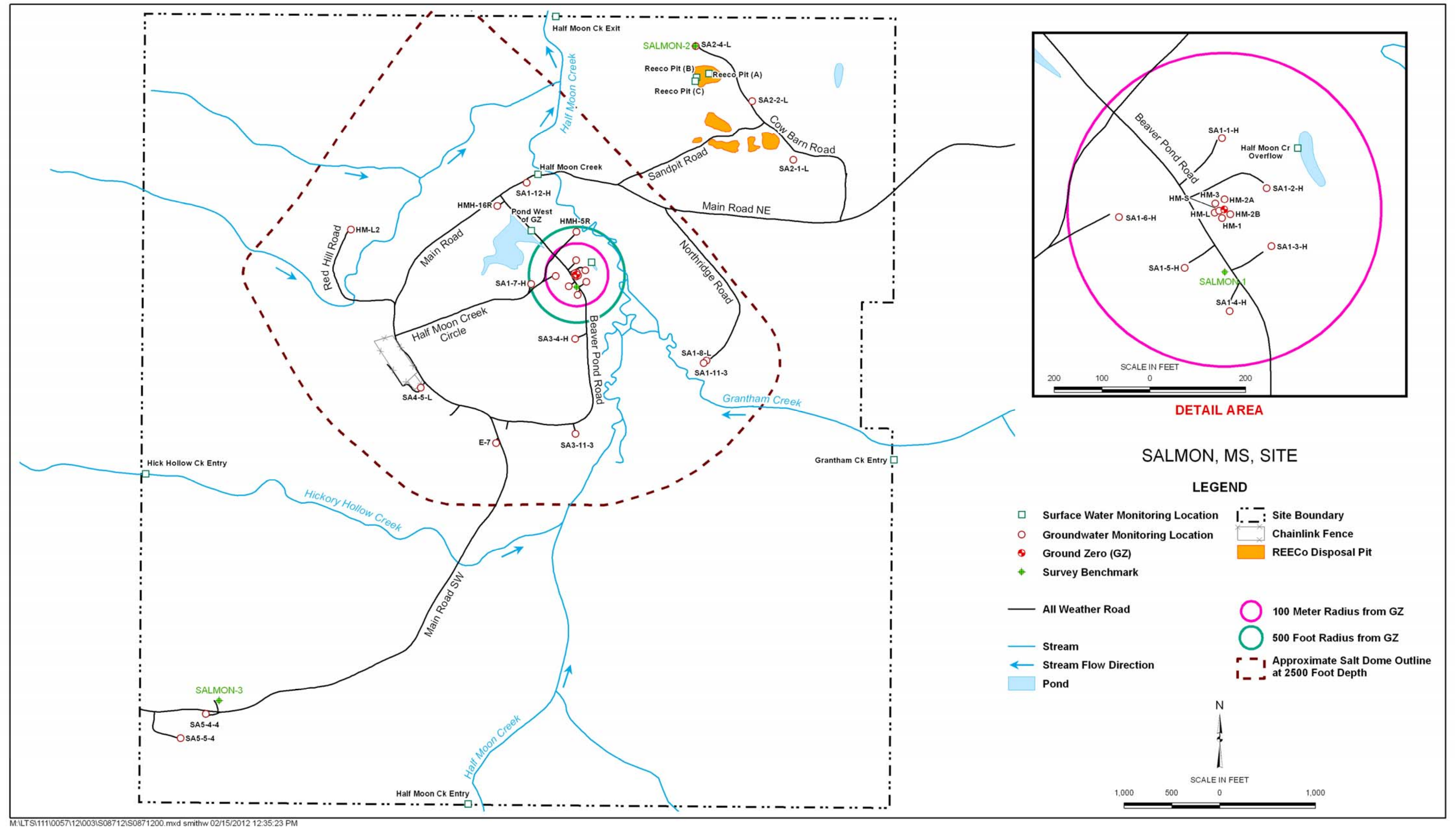

Figure 2. Sampling Locations within the Salmon Site 
This page intentionally left blank 
At two locations near ground zero, shallow contamination that could not be completely removed effectively and safely was left in place. These two locations are a rathole (used for vertical storage of drill pipe) and a drilling-mud pit. The contamination in the drilling mud consisted of tritium, metals, and volatile organic compounds (VOCs); the latter two are drilling-mud additives. The rathole is located beneath concrete that supports the concrete base of the monument at ground zero ${ }^{3}$. The mud pit is located nearby and covered with clean fill (centered at about $178 \mathrm{ft}, \mathrm{S} 16.5^{\circ} \mathrm{E}$ from ground zero). Some of the contaminated liquids removed during drill-back were injected into Aquifer 5, an aquifer used for brine disposal by the oil and gas industry. The injection borehole, located in the southwest corner of the site, was sealed after the injection.

Tritium brought to the surface during the drill-back operations has been detected in shallow groundwater samples collected by the U.S. Environmental Protection Agency (EPA) between 1972 and 2007, and subsequently by LM. In the monitoring wells where tritium has been detected, its concentration is attenuating faster than the rate predicted by the law of radioactive decay. No radioactivity from the detonations has been detected in the deep wells that monitor the plugged emplacement wells at ground zero or in the two deep wells that monitor Aquifer 5 where liquid radioactive material was injected. Figure 2 shows current surface-water sample points and monitoring well locations.

The potential source locations of residual contamination at the site are:

- $\quad$ The rathole and drilling-mud pit, both within $30 \mathrm{ft}$ of the surface.

- $\quad$ The cavity and the now-plugged ground-zero boreholes used during the tests.

- $\quad$ The wastes injected into Aquifer 5 and the borehole used to inject the wastes.

Locations associated with these sources are regularly monitored by LM (DOE 2007).

The contaminants of concern (COCs), determined from laboratory analytical results, are those with concentrations that exceed either the drinking water maximum contaminant level (MCL) (EPA 2011) or the Mississippi target remediation goal (TRG) (MDEQ 2002). Table 1 lists the COCs detected in water samples collected since 2004.

Table 1. Contaminants of Concern Detected Above the MCL or TRG Since 2004

\begin{tabular}{||l|l|l||}
\hline \multicolumn{1}{|c|}{ Radioactivity } & \multicolumn{1}{|c||}{ Metals } & \multicolumn{1}{|c||}{ Volatile Organic Compounds } \\
\hline Tritium & Arsenic $^{\text {a }}$ & Trichloroethene $^{\text {a }}$ \\
\hline & Barium $^{a}$ & cis-1,2-Dichloroethene \\
\hline & Chromium $^{\text {a }}$ & Vinyl chloride \\
\hline & Lead & \\
\hline \multicolumn{2}{l}{ Detected in groundwater above its MCL in 2011. }
\end{tabular}

\footnotetext{
${ }^{3}$ Ground zero is the surface point directly above the common center of the subsurface detonations. 
Tritium is listed as a COC because it is more mobile in groundwater than the other radioactive products resulting from a nuclear explosion. Since 2002, tritium has not been detected above its MCL (20,000 picocuries/liter $[\mathrm{pCi} / \mathrm{L}])$. The source of the arsenic is unknown and is unrelated to DOE activities.

Some compounds are deliberately left off the list of COCs in Table 1. Methylene chloride has been detected above the MCL, and naphthalene has been detected above the risk-based screening level (EPA 2011); however, the detections are few and irregular. Since naphthalene is a common solvent, and methylene chloride is a common laboratory contaminant, these compounds are judged not to be due to test activities.

The surveillance and maintenance objectives shown in Table 2 are used as guidance for regular inspections, institutional controls, water sample collection, water-level measurements, maintenance, and recordkeeping.

Table 2. Long-Term Surveillance and Maintenance Objectives for the Salmon, Mississippi, Site

\begin{tabular}{|c|c|}
\hline $\begin{array}{c}\text { Surveillance and } \\
\text { Maintenance Objective }\end{array}$ & Strategies to Achieve Objective \\
\hline $\begin{array}{l}\text { Prevent exposure to } \\
\text { radioactive materials } \\
\text { contained in the salt dome and } \\
\text { Aquifer } 5\end{array}$ & $\begin{array}{l}\text { - Monitor groundwater; evaluate results } \\
\text { - Monitor and maintain institutional controls }\end{array}$ \\
\hline $\begin{array}{l}\text { Control exposure to } \\
\text { contaminated groundwater }\end{array}$ & $\begin{array}{l}\text { - Monitor shallow surface and groundwater; evaluate results } \\
\text { - Monitor and maintain institutional controls }\end{array}$ \\
\hline $\begin{array}{l}\text { Maintain the physical integrity } \\
\text { of the site wells, pads, and } \\
\text { bollards, the survey } \\
\text { benchmarks, and the } \\
\text { monument at ground zero. }\end{array}$ & $\begin{array}{l}\text { - Conduct regular inspections } \\
\text { - Perform needed maintenance } \\
\text { - } \text { Maintain access controls } \\
\end{array}$ \\
\hline Prevent loss of knowledge & $\begin{array}{l}\text { - Comply with DOE requirements of mandatory surveillance and } \\
\text { maintenance program } \\
\text { - Communicate with regulators and stakeholders regularly (including public } \\
\text { education, outreach information, and notices) } \\
\text { - Record site institutional controls in Lamar County with real property records } \\
\text { and management agencies } \\
\text { - Comply with National Archives and Records Administration records } \\
\text { management requirements } \\
\text { - Maintain local records collection and make annual reports available }\end{array}$ \\
\hline
\end{tabular}

\section{Summary of 2011 Site Activities}

Water samples were collected and depth-to-water measurements made during the annual site sampling and inspection visit. A water-level measurement access tube was installed in a deep well, and weeds were mowed around on-site wells during a subsequent visit.

Selected images taken during site visits are included in Appendix A. Reference to a related image in Appendix A is included parenthetically throughout the text, as appropriate. Analytical results of sample analyses are in Appendix B. Appendix C shows trend plots of COCs through 2011. Appendix D tabulates the water-level elevations by quarter and shows hydrographs for three aquifers. 


\subsection{Inspection and Maintenance Activities}

\subsection{Institutional, Engineering, and Physical Controls}

\subsubsection{Deed restrictions and Ground Zero Monument}

The deed restriction prohibiting unauthorized penetration of the subsurface is on file with the Lamar County Chancery Clerk (page 212, Book 18-A, 25 August 2005). The deed restriction was attached to the quitclaim deed that enabled the transfer of the surface real estate to the State of Mississippi. The quitclaim transfer deed is filed with the Chancery Clerk (page 239, Book 21-M, 20 December 2010).

The quitclaim transfer deed has also been filed in the land record database of the US Bureau of Land Management, Jackson, Mississippi, office. A copy of the quitclaim transfer deed is available at http://www.lm.doe.gov/salmon/Documents.aspx.

A copy of the quitclaim transfer deed was provided to the Purvis Public Library for their Salmon document collection.

The Lamar County Planning Department was provided a copy of the deed restriction. They will annotate the county planning records to notify DOE if a zoning change is considered for the Salmon site.

An order for a new bronze monument plaque was made so as to correct language on the existing plaque (Appendix A, Image A-1). The language on the replacement plaque is:

NO EXCAVATION, DRILLING, AND/OR REMOVAL OF MATERIALS IS PERMITTED WITHOUT U.S. GOVERNMENT PERMISSION TO PENETRATE INTO THE SUBSURFACE BELOW THE 1470 ACRE TRACT SITUATED WITHIN SECTIONS 11, 12, 13, AND 14, T2N, R16W, ST. STEPHENS MERIDIAN, MISSISSIPPI.

Installation of the new plaque is planned for April 2012.

\subsubsection{Fences}

The site perimeter fence is nonfunctional. Dense vegetation limits access along most of the perimeter.

\subsubsection{Gates and Locks}

There are two gates to the site; one at the main site entry on Main Road NE and the other on Main Road SW (see Figure 3). Both gates and the locks on them are in good condition.

\subsubsection{Signs}

The DOE "No Trespassing" signs are still posted at the gates and at some perimeter locations.

The State has agreed not to conduct logging operations within $500 \mathrm{ft}$ of ground zero (see Figure 3). A future plan is to post a few signs along the $500 \mathrm{ft}$ perimeter. 


\subsection{Physical Site Conditions}

Weeds around the wellheads were observed to be overgrown during the April inspection (Appendix A, Image A-2). Weeds constitute a hazard to visibility and are a fire hazard near the wellheads during dry weather conditions. The dedicated bladder pump in each of the 26 wells is suspended by a pair of polyethelyne tubes from the top of the casing. If nearby weeds burn, the heat on the tubing puts the dedicated pump at risk of falling to the bottom of the well.

The weeds around each well were cut with a bush hog in July (Appendix A, Image A-3).

Roads to the monitoring wells were in good condition.

In preparation for logging operations, former roads and trails have been cleared of brush and bladed by the Mississippi Forestry Commission.

\subsection{Monitoring Wells}

There are 28 active groundwater monitoring wells on the Salmon site. The wells are used to monitor groundwater in the aquifers below the site.

Six wells monitor the test cavity and plugged emplacement test wells at ground zero. The aquifers above the salt dome (listed from deepest to shallow) are Caprock Aquifer, Aquifer 3, Aquifer 2B, Aquifer 2A, Aquifer 1, Local Aquifer, and Alluvial Aquifer.

Twelve wells monitor the Alluvial Aquifer in the ground zero area. One of these wells also monitors the plugged test wells at ground zero.

Seven wells monitor the Local Aquifer. One of these wells is used to monitor the plugged test wells at ground zero. The Local Aquifer is a source of drinking water offsite.

Three wells monitor Aquifer 3. One of these wells is used to monitor the plugged test wells at ground zero.

Two deep wells in the southwest corner of the site monitor Aquifer 4 for leakage from Aquifer 5.

One well is in the Caprock Aquifer.

Dedicated bladder pumps are installed in 26 of the 28 wells. Dedicated submersible Grundfos electric pumps are installed in the two deep wells in Aquifer 4. 


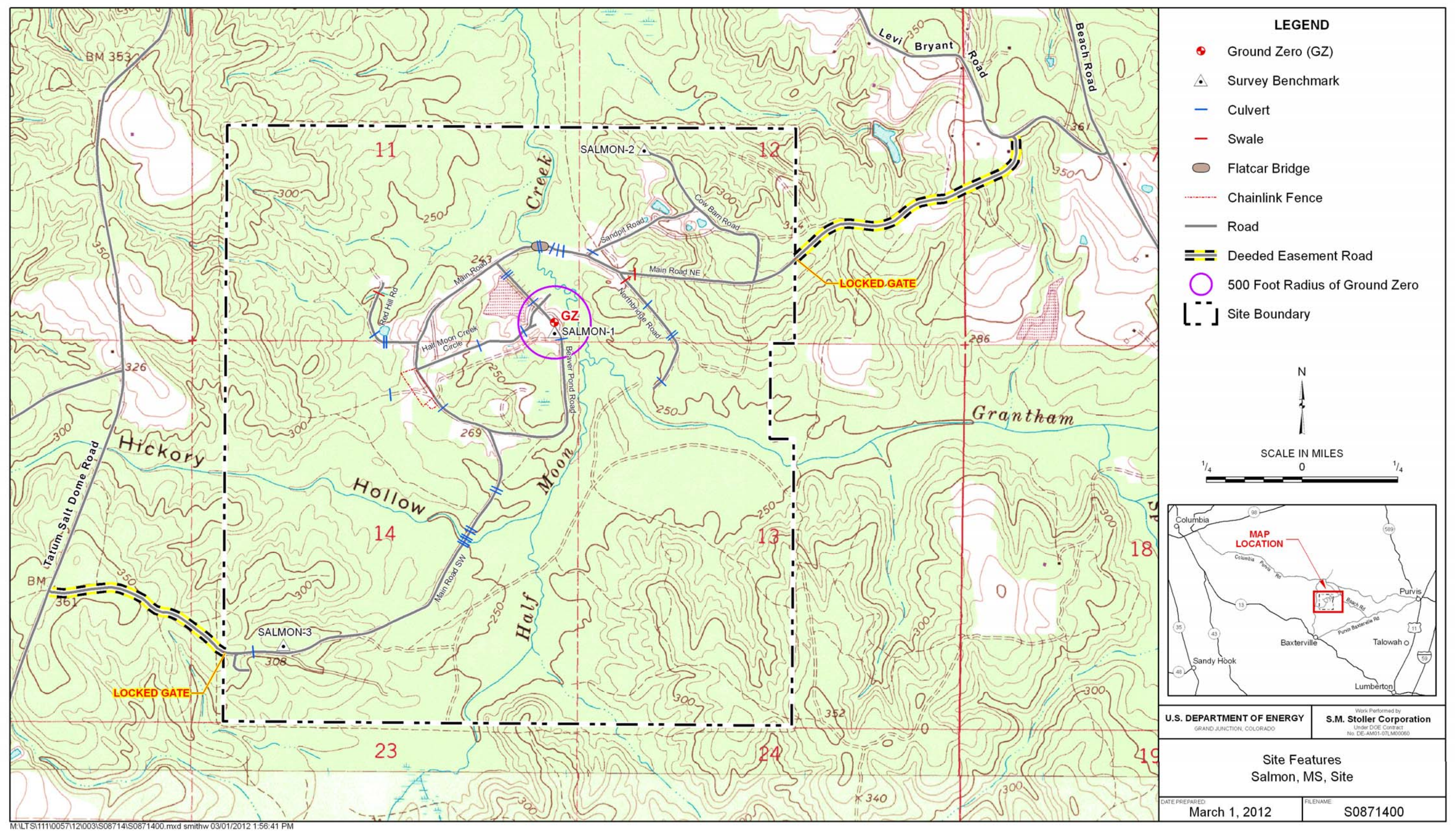

Figure 3. Topographic Map of the Salmon Site with Road Features 
This page intentionally left blank 
Samples are collected (Appendix A, Image A-4) according to accepted standards for low-flow sampling (ASTM 2007). Samples of purge water collected from certain wells in 2010 contained contaminants at concentrations above the MCL for drinking water. In 2011, the purge water from these wells (Appendix A, Image A-5) — about 1 gallon per well—was containerized, mixed together, and discarded because dilution reduces the composite concentration to levels below the respective MCLs. However, purge water from well HMH-5R contains trichloroethene (TCE), which must be treated due to its concentration level. This purge water (about 1 gallon) was treated in the field by sparging to reduce the TCE concentration to a level below its MCL. A sample was collected for TCE analysis to determine if 1 hour of sparging is sufficient. The analysis result was $5.6 \mu \mathrm{g} / \mathrm{L}$. The MCL for TCE is $5.0 \mu \mathrm{g} / \mathrm{L}$. In 2012, the sparging time will be increased.

Diluted or treated purge water is not regulated under any waste regulations except that it cannot be placed back into the aquifer, discharged to state surface waters, or discharged to the ground if contaminant levels knowingly exceed state TRGs or MCLs.

A typical monitoring well is surrounded by a protective metal casing, painted white, with a locked, metal cover. At the base is a rectangular concrete pad. At each corner of the pad stands a $4 \mathrm{ft} \mathrm{high} \mathrm{bollard}{ }^{4}$ painted bright "safety orange." A three-bollard set surrounds each of the three surveyor benchmarks. The protective well casings, covers, concrete pads, and bollards were in good condition. The bollards protecting the benchmarks were in good condition.

In a number of wells, the brass coupling in the air-supply side of the flex-flow adaptor well cap is cracked. The well cap assembly supports the bladder pump by a pair of 0.25 -inch-diameter polyethylene tubes: one tube for pressurized air to the pump and the other for the water sample from the pump.

A new 1.5-inch-diameter PVC water-level access pipe was installed in well SA5-4-4 (Appendix A, Image A-6). The purpose of the access pipe is to facilitate manual measurements of water level in the well.

Water-level data loggers were installed in wells SA5-4-4 and SA5-5-4.

\subsection{Site Ecology Conditions}

The gopher tortoise is a federally listed threatened species. The tortoise is listed as endangered by the State of Mississippi. No active tortoise burrows were observed in the vicinity of the 28 monitoring wells, the three benchmarks, or the monument at ground zero.

No beavers or beaver activity were observed near access roads to monitoring wells.

\footnotetext{
${ }^{4}$ A bollard is a concrete pipe, here 4-inch diameter, filled with concrete and set in concrete below ground. 


\subsection{Public Information Access}

The Post-Closure Inspection, Sampling, and Maintenance Report for the Salmon, Mississippi, Site Calendar Year 2010 (DOE 2011) was posted on the LM webpage (http://www.lm.doe.gov/salmon/Sites.aspx).

The Data Validation Package (DOE 2012) was also posted on the LM webpage. This report contains results from the laboratories that analyzed the water samples collected during April 2011 and summarized here.

The report on the confirmatory tree-wood study (DOE 2010) and a copy of the quitclaim surface real estate transfer deed were added to the Salmon document collection at the Purvis Public Library.

\subsection{Analytical Results}

Groundwater samples were collected from each of the 28 active onsite wells. Surface water samples were collected from 8 of 10 onsite locations and one offsite location (Appendix A, Image A-7). Water samples at two surface locations were not collected due to lack of water.

Separate samples for metals analyses were not collected in the field. Instead, new 40-milliliter glass sample bottles were sent to the EPA Radiation and Indoor Environments National Laboratory in Las Vegas, Nevada. EPA decanted a sample from the excess in each of the samples previously received for tritium analysis. The 9, 40-milliliter, decanted samples were shipped from Las Vegas via overnight courier to ALS Paragon laboratory in Ft. Collins, Colorado, for the metals analyses.

The 37 water samples were analyzed for tritium. Selected surface water and groundwater samples were analyzed for VOCs, metals, gamma-emitting radionuclides, or some combination. Tabulated laboratory results are given in Appendix B. The EPA MCLs (EPA 2011) and State TRGs (MDEQ 2002) are the groundwater and surface water standards.

Temperature, $\mathrm{pH}$, turbidity, and conductivity were measured in the field before each well was sampled (Appendix A, Image A-8).

Samples were analyzed by ALS Paragon for a suite of VOCs and selected metals (Resource Conservation and Recovery Act metals - arsenic, barium, cadmium, chromium, lead, selenium, silver, and mercury — plus antimony, beryllium, nickel, and zinc).

Samples for radiochemistry analyses of standard tritium, enriched tritium, and high-resolution gamma spectroscopy were shipped to the EPA Radiation and Indoor Environments National Laboratory in Las Vegas. The samples were sent from the Las Vegas laboratory to EPA's National Air and Radiation Environmental Laboratory in Montgomery, Alabama for tritium analysis and gamma spectroscopy. 
Typically, 25 percent of the collected water samples are analyzed by the more sensitive enriched tritium method. EPA discontinued enriched tritium analysis in 2011, so no results for enriched tritium analysis are reported in this report.

Tritium was detected in three groundwater samples at concentrations above the MDC (see Appendix B, Table B-1, samples without a "J" qualification). In 2010, tritium was detected in five samples analyzed by the standard tritium method at concentrations above the MDC. The highest tritium result of the three samples in 2011 was $4,600 \mathrm{pCi} / \mathrm{L}$ in shallow well $\mathrm{SA} 1-1-\mathrm{H}$. This result is an increase of 11 percent from the concentration detected in 2010 and a familiar pattern for tritium concentration in this well (see Appendix C, Figure C-2).

No tritium was detected in the nine surface-water samples analyzed by the standard method. In 2010, no tritium analyzed by the standard method was reported, and only one enriched tritium result was reported without data qualifications.

No gamma-emitting elements were detected in any sample analyzed by the high-resolution gamma spectroscopy method.

Analytical results are tabulated in Appendix B. Tritium concentrations in groundwater samples, above the laboratory-determined MDC, are listed in Table B-1. VOCs and metals in groundwater, above the laboratory-determined detection limits, are in Table B-2. Metals in surface waters, above respective detection limits, are in Table B-3. Some results in the tables are qualified.

\subsection{Sample Results Greater than Standards}

Thirty-seven groundwater, nine surface water, and five duplicate samples were submitted to two laboratories for tritium, VOCs, and metals analyses. The laboratories returned 290 analytical results, including the results for the duplicate samples. Excluding the duplicate sample results, 231 results were returned and 212 were above the laboratory-determined detection limit (or MDC): 6 tritium, $30 \mathrm{VOC}$, and 117 metals results in groundwater, and 59 metals results in surface water. Six groundwater samples from six locations had a VOC or metal concentration that exceeded its MCL or TRG. The results and relevant standards are in Table 3, listed by location.

Table 3. 2011 Analytical Results of Groundwater Exceeding the MCL or TRG

\begin{tabular}{||c|c|c|c|c||}
\hline \hline Location & Date Sampled & Analyte & Result (mg/L) & $\begin{array}{c}\text { MCL or TRG } \\
\text { (mg/L) }\end{array}$ \\
\hline SA1-3-H & 19 April 2011 & Arsenic & 0.015 & 0.010 \\
\hline SA1-7-H & 20 April 2011 & Arsenic & 0.011 & 0.010 \\
\hline SA4-5-L & 19 April 2011 & Barium & 2.600 & 2.000 \\
\hline HM-3 & 18 April 2011 & Chromium & 0.120 & 0.100 \\
\hline HMH-5R & 20 April 2011 & Trichloroethene & 0.100 & 0.005 \\
\hline SA1-1-H & 19 April 2011 & Trichloroethene & 0.006 & 0.005 \\
\hline
\end{tabular}

$\mathrm{mg} / \mathrm{L}=$ milligrams per liter $\left(1 \times 10^{-3}\right.$ gram per liter $)$ 
In 2010, laboratory results of samples collected at six groundwater locations were above the respective standard. The first five locations listed in Table 3 are the same as in 2010, with the same analyte, only the result is different.

\subsection{Contaminant Concentration Trends}

Concentration trends through 2011 for COCs are plotted in Appendix C.

Tritium concentrations in groundwater are plotted in Figures $\mathrm{C}-1$ through $\mathrm{C}-6$, and surface water concentrations are plotted in Figures $\mathrm{C}-7$ and $\mathrm{C}-8$. For comparison, tritium in precipitation (at Ottawa, Canada) is also plotted (Lehr and Lehr 2000) along with a tritium decay trend line. The law of radioactive decay is described by exponential decay. When exponential decay is plotted on a vertical logarithmic scale versus a linear horizontal scale (time), the decay trend is a straight line. The half-life of tritium is 12.32 years.

The plots of tritium concentration in groundwater are grouped by location. Figure $\mathrm{C}-1$ is a plot of tritium concentration trend for the six aquifers above the salt dome at ground zero. Tritium trends in Figures C-2 and C-3 are plotted for wells "near" and "far" from ground zero in the Alluvial Aquifer. Figures C-4 through C-6 show tritium trends for the Local Aquifer, Aquifer 3, and Aquifer 4, respectively.

The tritium concentration trends in surface-water locations near ground zero and three locations in the REECo pit area are plotted in Figures $\mathrm{C}-7$ and $\mathrm{C}-8$, respectively.

Figures C-9 through C-16 are concentration-trend plots of selected VOCs or metals that exceed the respective standards in 2011 or have exceeded the standards in the past.

All concentration trends for tritium and other COCs appear to be constant or decreasing except for the tritium concentration in the Alluvial Aquifer in well SA1-1-H (see Figure C-2). Although the groundwater tritium concentration in well HMH-5R is higher than in 2010, the increase is judged a statistical fluctuation; the overall trend appears to be decreasing (Figure C-3).

\subsection{Water-Level Measurements}

Water levels in the onsite monitoring wells are measured quarterly (Appendix A, Image A-9). The Mississippi Department of Health, Division of Radiologic Health measures water levels during the first, third, and fourth quarters. LM measures water levels during the second quarter.

Quarterly water-level elevations per well determined from quarterly depth-to-water measurements are given in Appendix D, Table D-1 along with hydrographs for the Alluvial Aquifer, Local Aquifer, and Aquifer 3. 


\subsection{Recommendations}

Make alternate plans for laboratory radiochemistry analyses in 2012.

Install the new replacement plaque on the monument at ground zero.

Repair the leaking well cap assemblies.

Install perimeter signs, $500 \mathrm{ft}$ from the ground zero monument, that caution about below-grade penetration without DOE approval.

\subsection{References}

ASTM (American Society for Testing and Materials), 2007. "Standard Guide for Sampling Ground-Water Monitoring Wells," D 4448-01, October.

DOE (U.S. Department of Energy), 2007. Long-Term Surveillance and Maintenance Plan for the Salmon Site, Lamar County, Mississippi, Draft, DOE-LM/1447-2007, Rev. 1, Office of Legacy Management, Grand Junction, Colorado, April.

DOE (U.S. Department of Energy), 2010. Confirmatory Tree Sampling for Tritium in Trees at the Salmon Site, Mississippi, LMS/SAL/S06677, Office of Legacy Management, Grand Junction, Colorado, June.

DOE (U.S. Department of Energy), 2011. Post-Closure Inspection, Sampling, and Maintenance Report for the Salmon, Mississippi, Site Calendar Year 2010, LMS/SAL/S07531 Office of Legacy Management, Grand Junction, Colorado, March.

DOE (U.S. Department of Energy), 2012. Data Validation Package April 2011 Groundwater and Surface Water Sampling at the Salmon, Mississippi Site, LMS/SAL/S00411, Office of Legacy Management, Grand Junction, Colorado, January.

EPA (U.S. Environmental Protection Agency), 2004. 2004 Edition of the Drinking Water Standards and Health Advisories, EPA 822-R-04-005, Winter.

Lehr, J.H., and J.K. Lehr, 2000. Standard Handbook of Environmental Science, Health, and Technology, Figure 4.7.9, The McGraw-Hill Companies, p. 4.70, July 27.

MDEQ (Mississippi Department of Environmental Quality), 2002. Subpart 11, Risk Evaluation Procedures for Voluntary Cleanup and Redevelopment of Brownfield Sites, http://www.deq.state.ms.us/mdeq.nsf/pdf/GARD_brownfieldrisk/\$File/Proced.pdf?OpenElement accessed 27 February 2012. 
This page intentionally left blank

Post-Closure Inspection, Sampling, and Maintenance Report, Salmon, Mississippi, Calendar Year 2011

Doc. No. S08711

U.S. Department of Energy

Page 16 


\section{Appendix A}

\section{Selected 2011 Images}


This page intentionally left blank 


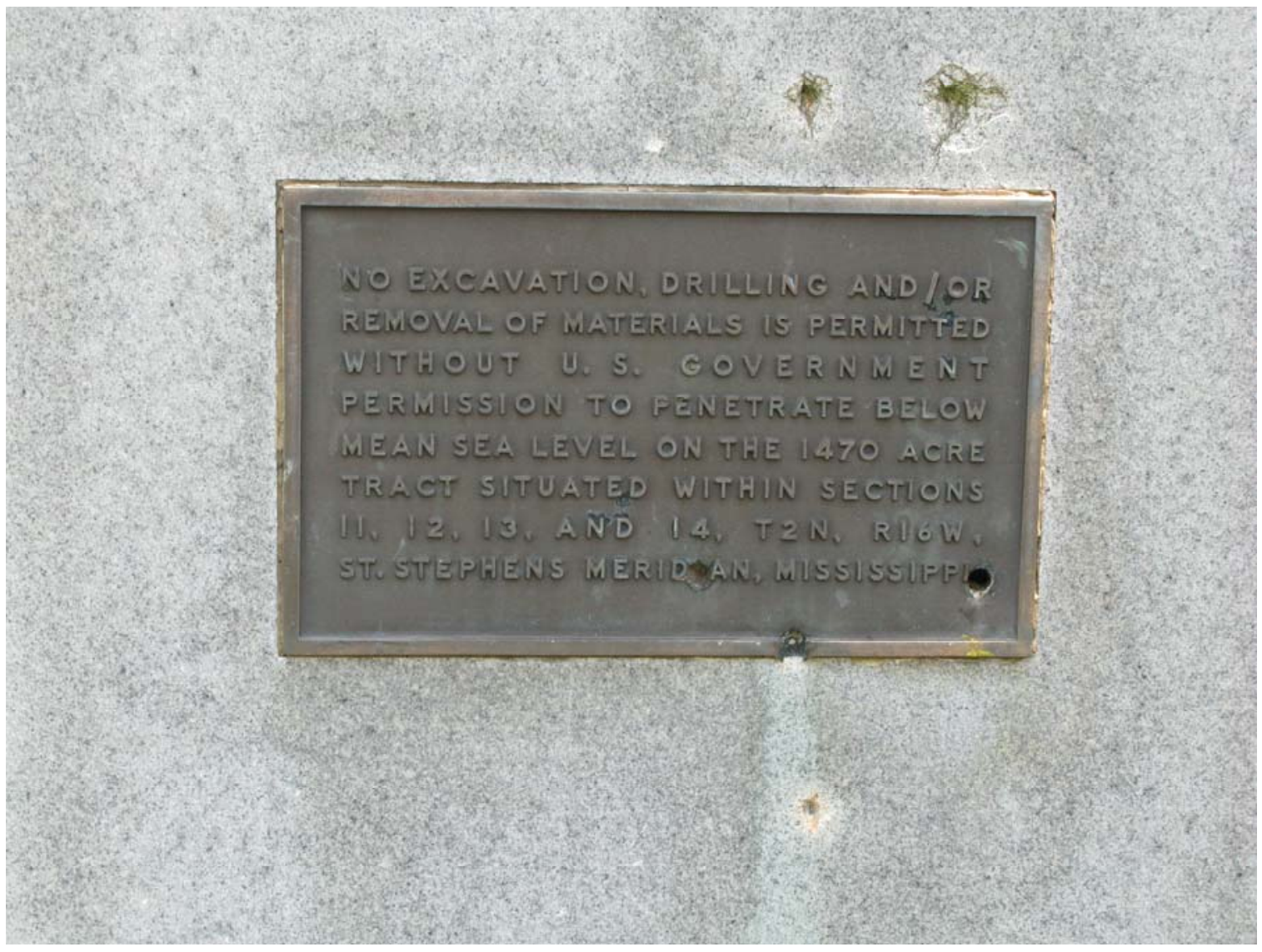

Image A-1. Ground-zero monument plaque to be replaced by the new bronze plaque. 


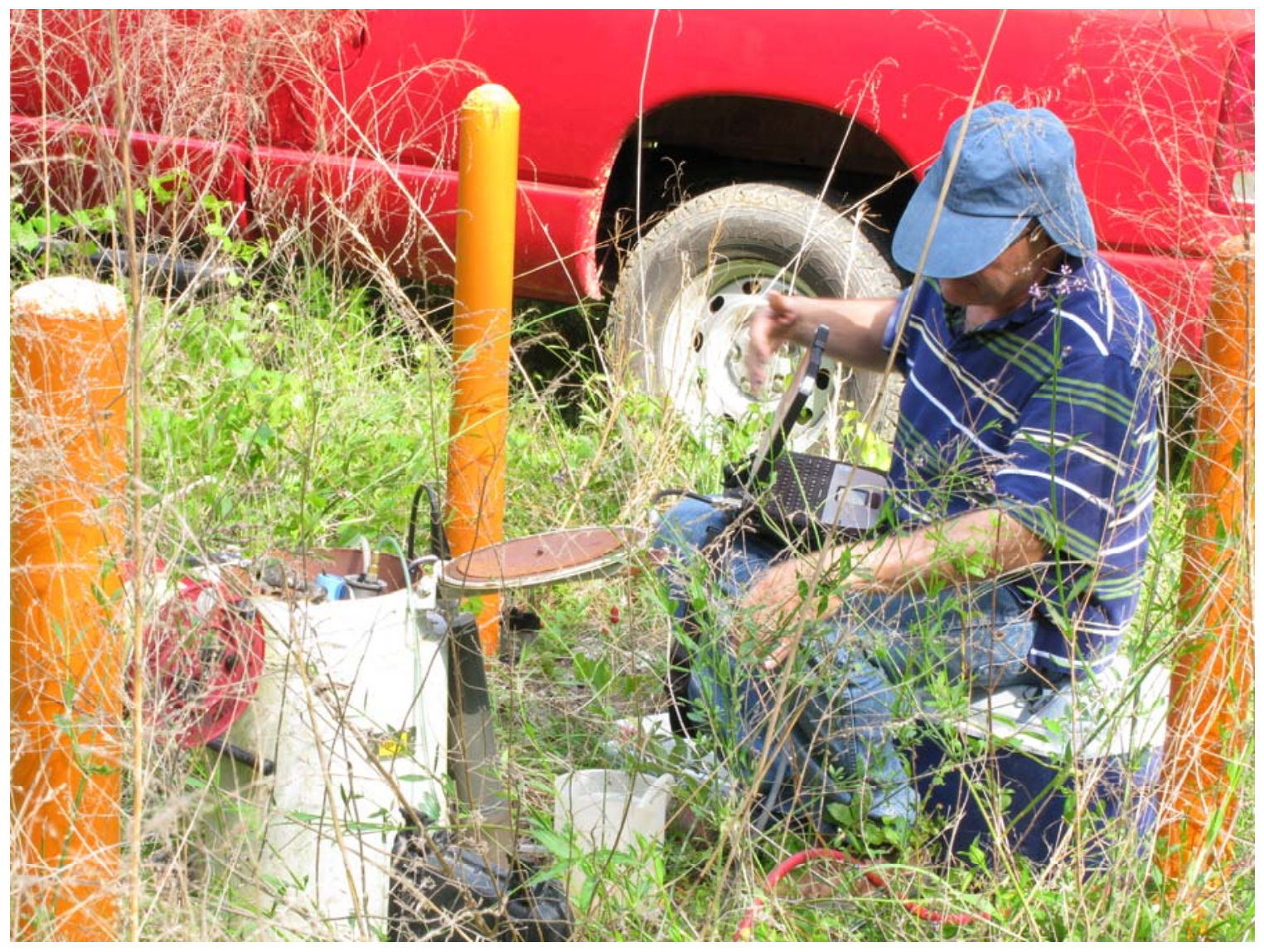

Image A-2. The technician is preparing to collect a water sample pumped from well HM-L2. The sample bottle is in his left hand. 


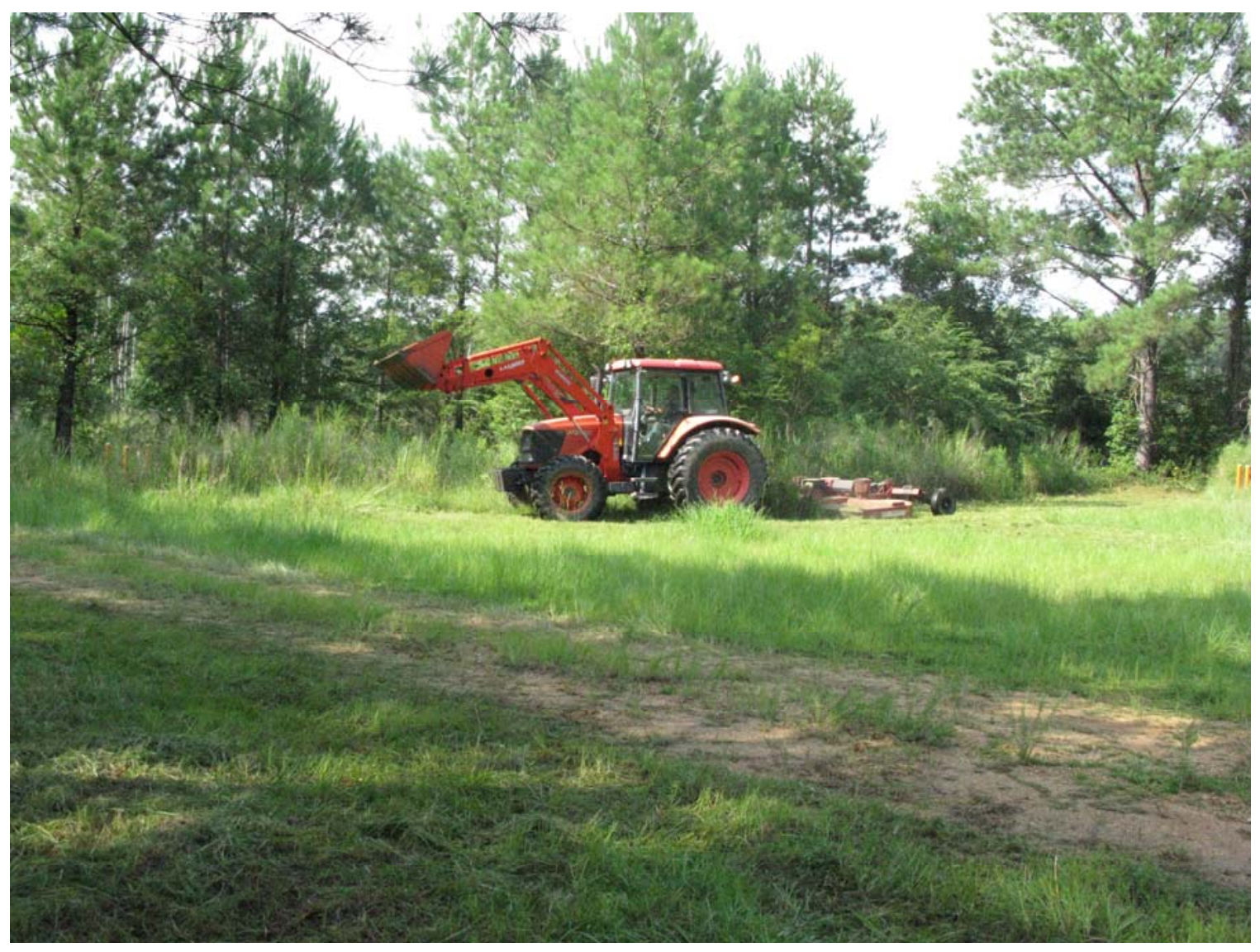

Image A-3. A tractor pulls a bush hog mowing weeds near ground zero. The benchmark Salmon \#1 is on the left, protected by three orange bollards (faintly visible) and two of the four bollards surrounding well SA1-5-H are at the right edge of the image. The view is to the south. 


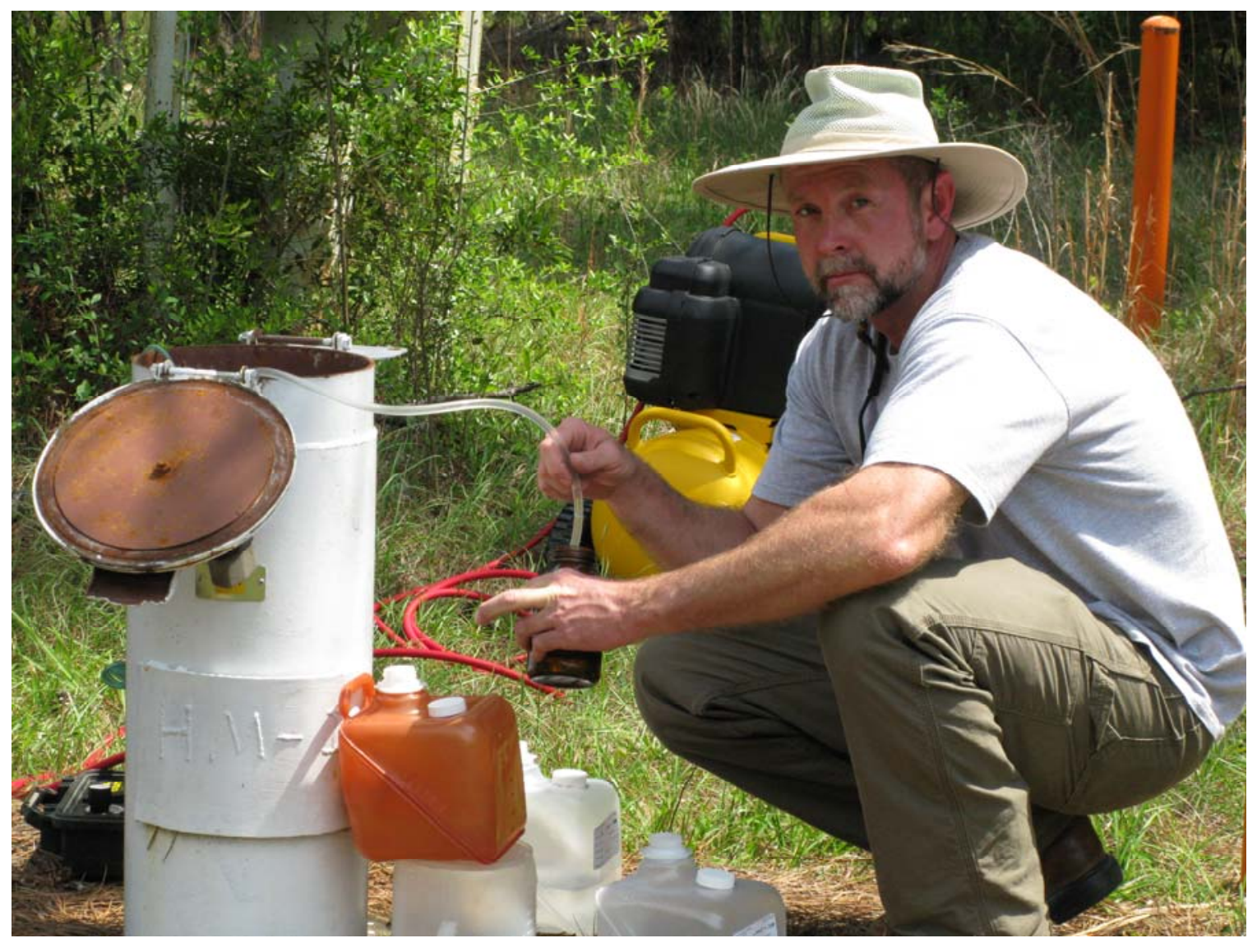

Image A-4. Collecting a groundwater sample by the low-flow method at well HM-3. 


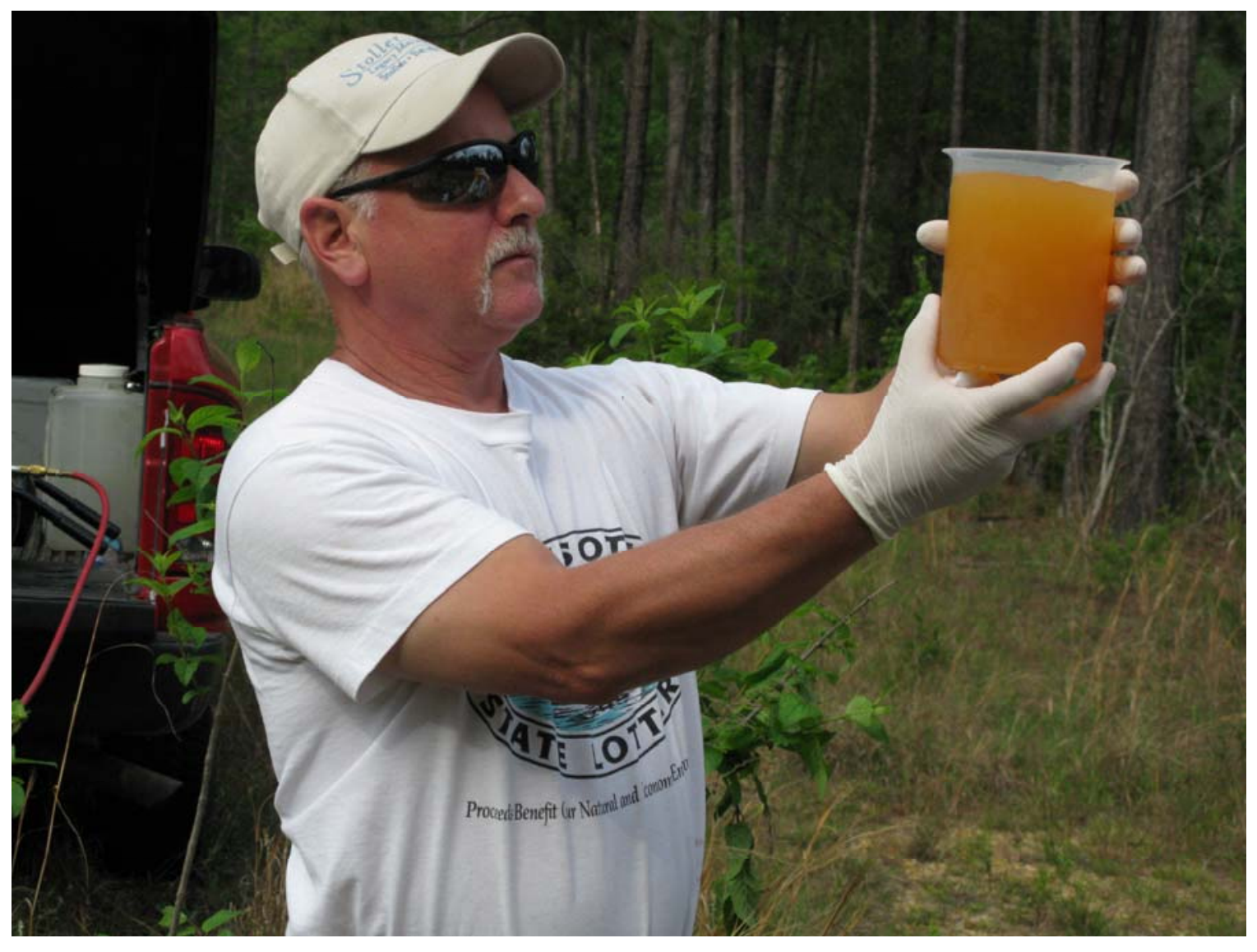

Image A-5. Purge water collected from well SA1-6-H is examined. 


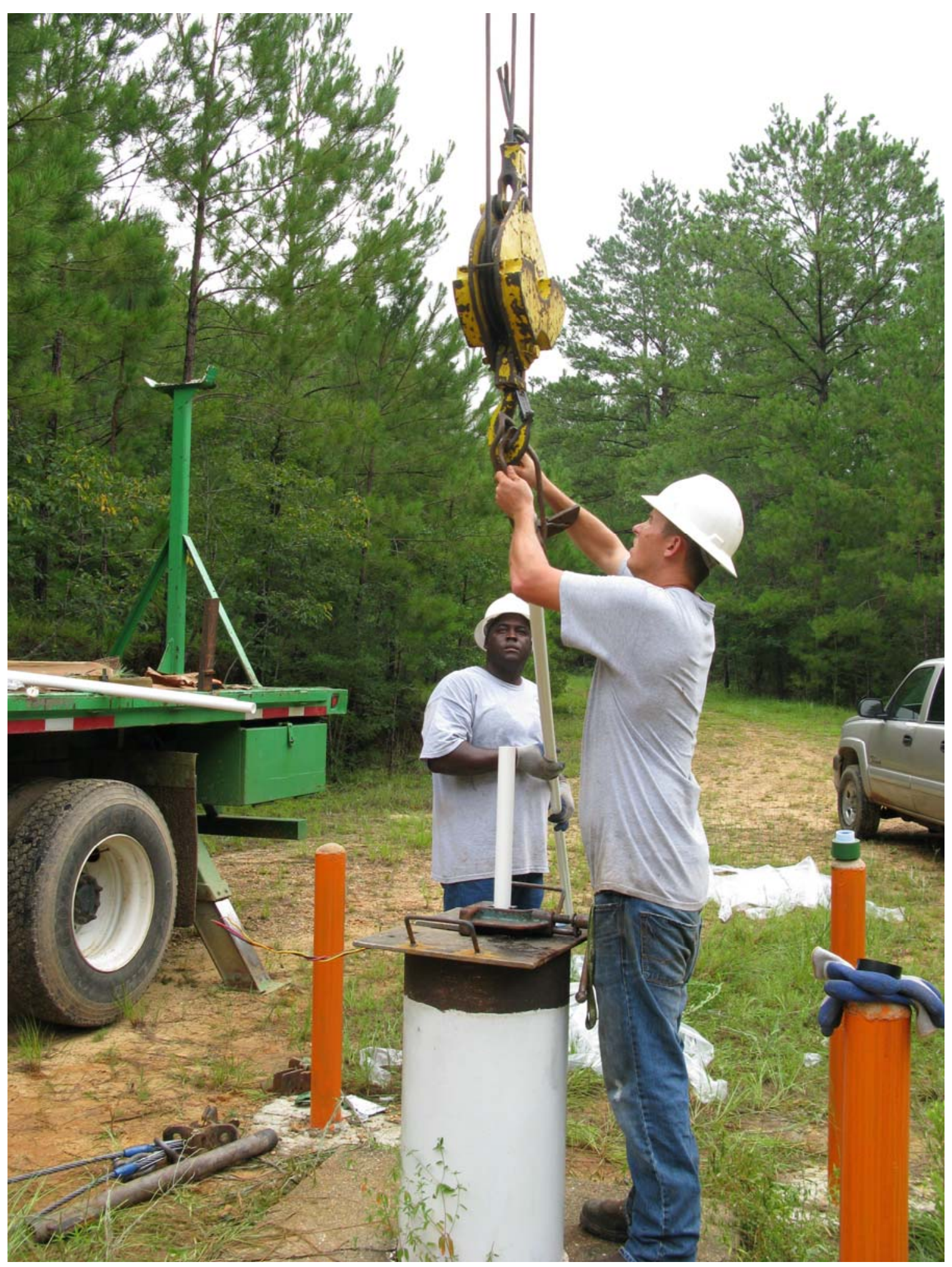

Image A-6. A section of PVC tubing to be installed is connected to the crane's hook. A section of PVC access tubing already installed in the well is suspended by a vice (center) on the plate placed across the protective well casing (white). 


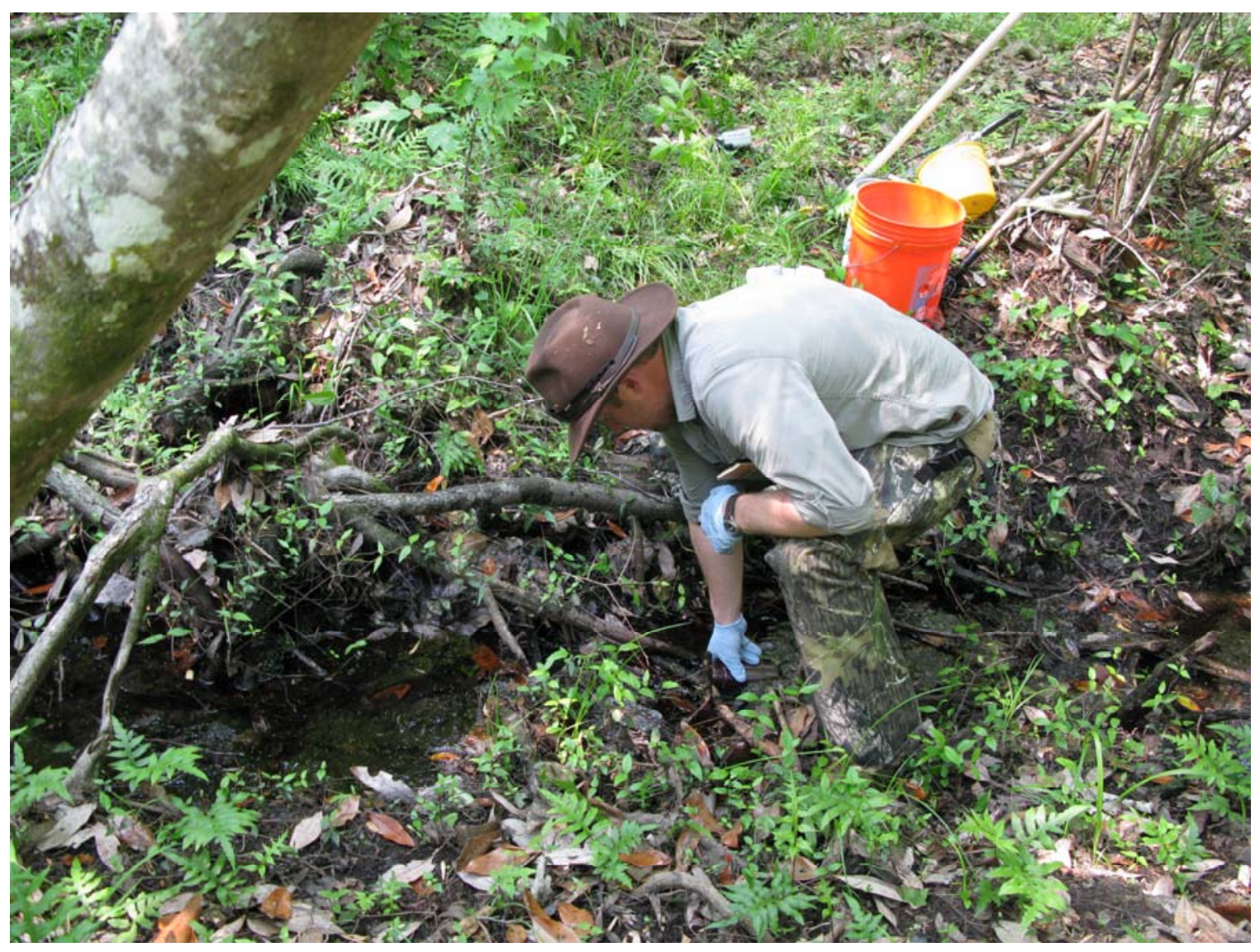

Image A-7. A surface-water sample is collected at the location designated REECo Pit A. 


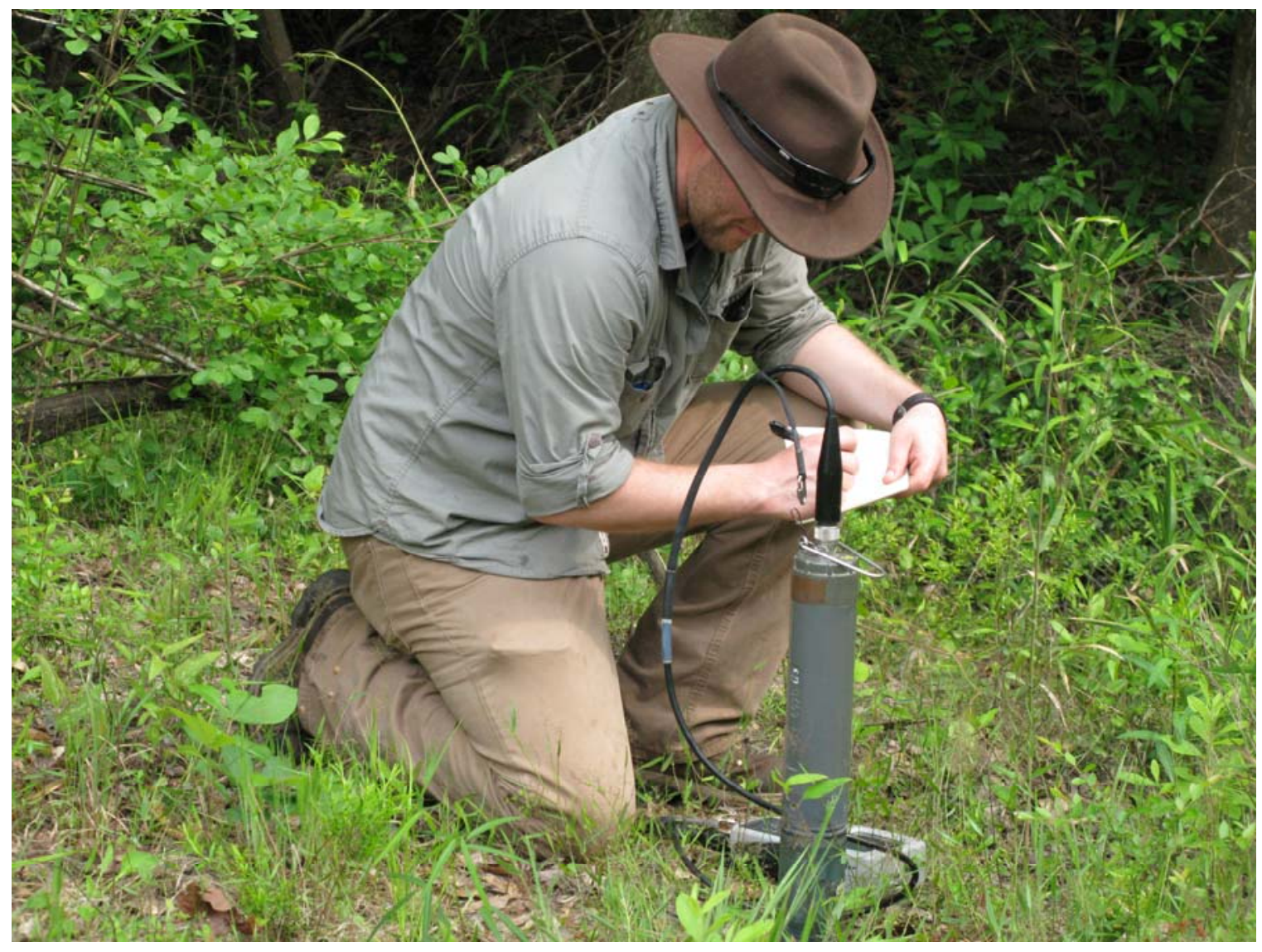

Image $\mathrm{A}-8$. The $\mathrm{pH}$, conductivity, oxidation-reduction potential, and temperature parameters are measured in a surface water sample collected where Grantham Creek enters the Salmon site from the east. 


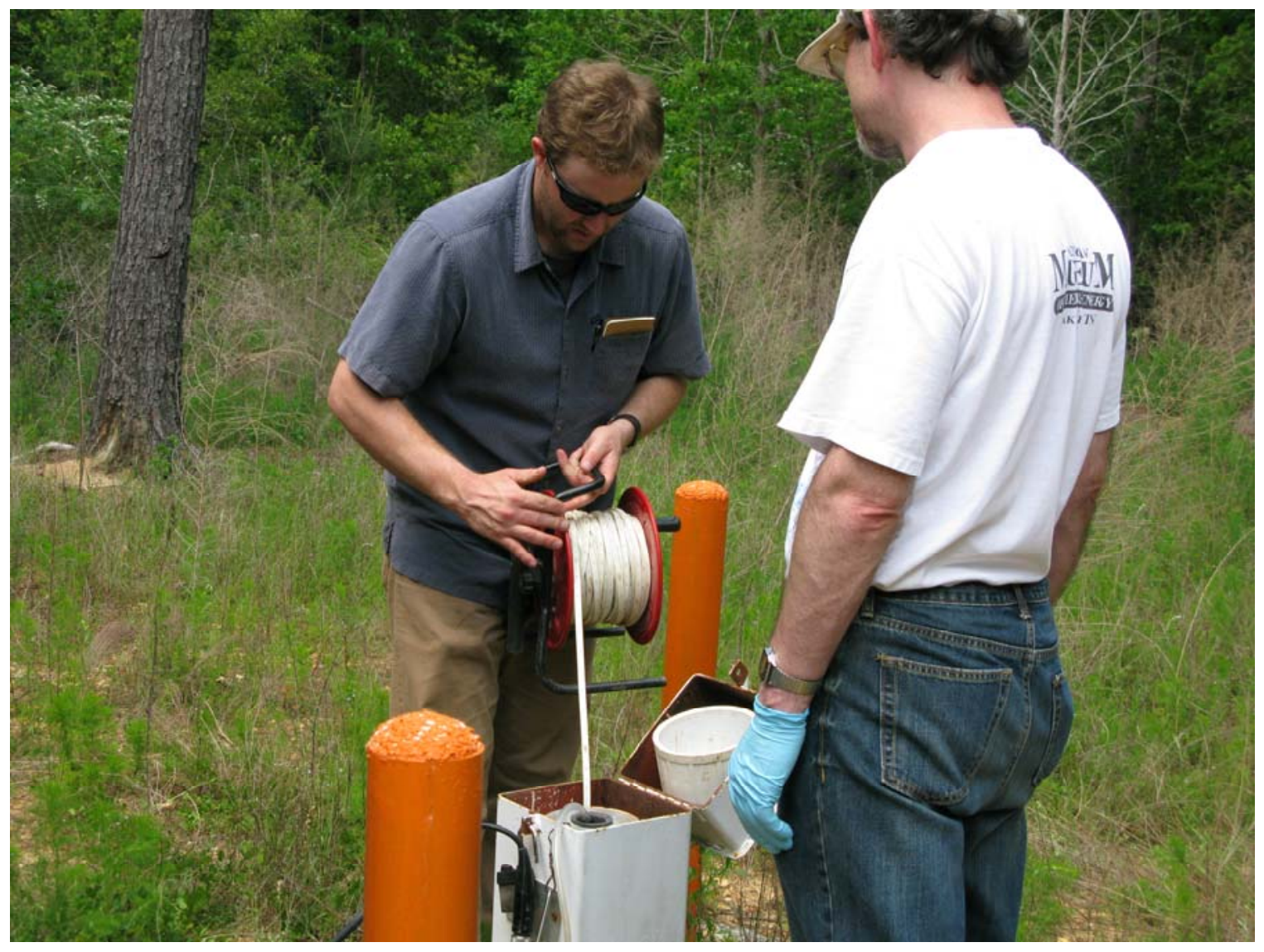

Image A-9. The technician is observed making a depth-to-water measurement. 


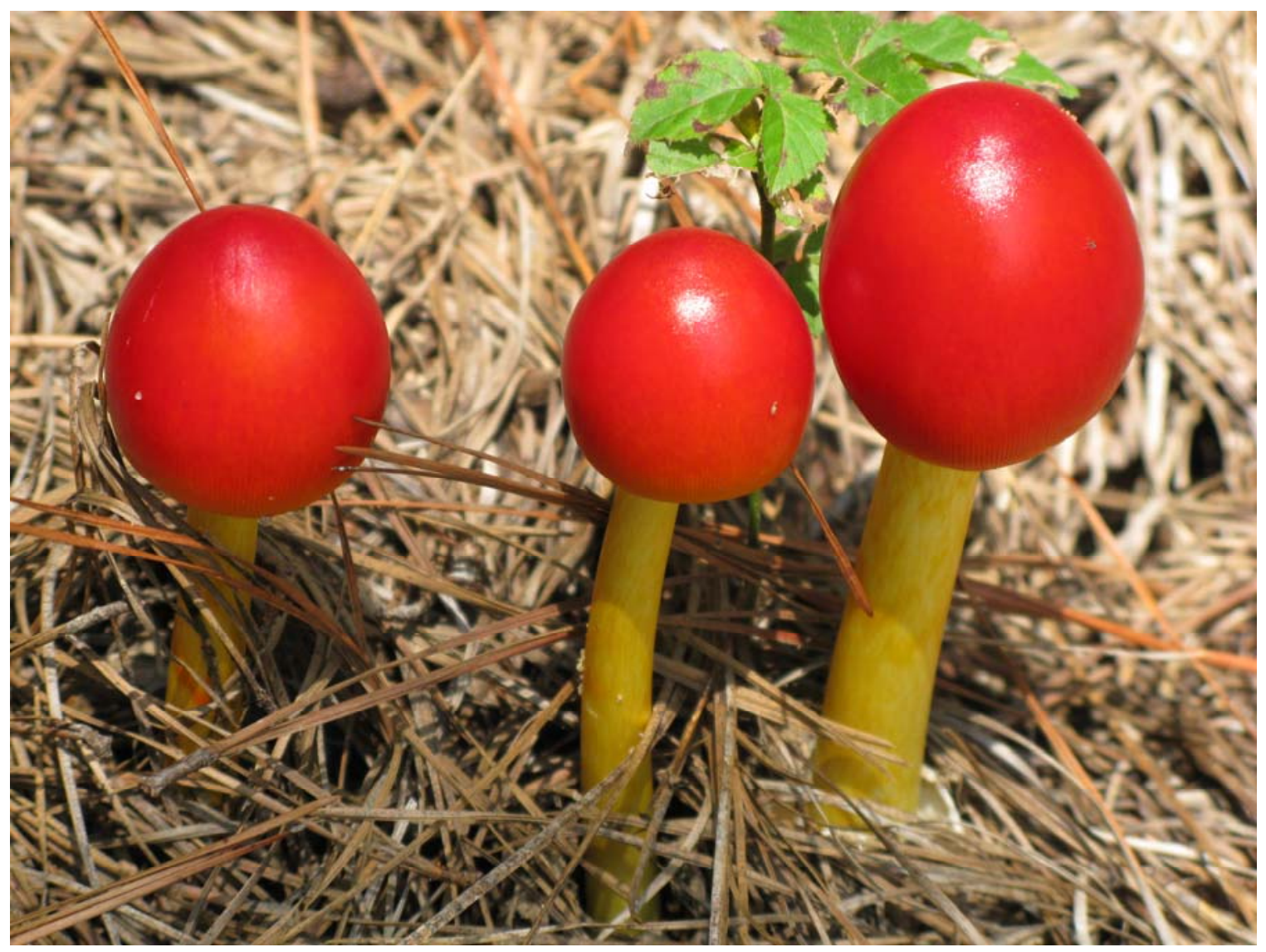

Image A-10. Scarlet waxycup (hygrophorus miniatus) growing near the Salmon-3 benchmark. 
Appendix B

2011 Laboratory Analytical Results 
This page intentionally left blank 
Table B-1. Tritium Detected above the Minimum Detectable Concentration (MDC) in Groundwater Samples Collected during April 2011

\begin{tabular}{||l|c|c|c|c|c|c||}
\hline \multicolumn{1}{||}{ Location } & Date & Analyte & $\begin{array}{c}\text { Result } \\
(\mathbf{p C i / L )}\end{array}$ & $\begin{array}{c}\text { Lab } \\
\text { Qualifiers }\end{array}$ & $\begin{array}{c}\text { Data } \\
\text { Validation } \\
\text { Qualifiers }\end{array}$ & $\begin{array}{c}\text { MCL or } \\
\text { TRG }\end{array}$ \\
\hline HM-L & 18-Apr-11 & Tritium & 806 & & $\mathrm{~F}$ & \\
\hline HM-S & $18-A p r-11$ & Tritium & 361 & & JF & \\
\hline HM-S (dup) & 18-Apr-11 & Tritium & 367 & & JF & \\
\hline SA1-3-H & 19-Apr-11 & Tritium & 258 & & JF & \\
\hline SA1-1-H & 19-Apr-11 & Tritium & 4600 & & F & \\
\hline SA1-2-H & 19-Apr-11 & Tritium & 347 & & JF & \\
\hline HMH-5R & 20-Apr-11 & Tritium & 1310 & & F & \\
\hline
\end{tabular}

Typically, $25 \%$ of the samples submitted for tritium analysis are also analyzed by the enriched method. The enriched tritium method was not performed in 2011 due to a laboratory issue.

(dup) duplicate sample result

Data Validation Qualifiers:

F: $\quad$ Field sample collected by the low-flow method.

$\mathrm{J}$ : $\quad$ Estimated-the result is less than three times the detection limit.

\section{Statistics}

7 Results greater than the minimum detection concentration

1 Duplicate

$6 \quad$ Unique results

0 Results greater than the MCL or TRG 
Table B-2. Volatile Organic Compounds and Metals That Were Detected above the Detection Limit in Groundwater Samples Collected in April 2011. Results above the MCL or TRG are in Bold.

\begin{tabular}{|c|c|c|c|c|c|c|c|}
\hline Location & $\begin{array}{c}\text { Date } \\
\text { Sampled }\end{array}$ & Analyte & Result & Units & $\begin{array}{c}\text { Lab } \\
\text { Qualifiers }\end{array}$ & $\begin{array}{c}\text { Data } \\
\text { Validation } \\
\text { Qualifiers }\end{array}$ & $\begin{array}{l}\text { MCL or } \\
\text { TRG }\end{array}$ \\
\hline $\mathrm{E}-7$ & 19-Apr-11 & Benzene & 0.19 & $\mu g / L$ & $\mathrm{~J}$ & $\mathrm{~F}$ & \\
\hline E-7 (dup) & 19-Apr-11 & Methylene chloride & 0.19 & $\mu \mathrm{g} / \mathrm{L}$ & BJ & UF & \\
\hline $\mathrm{E}-7$ & 19-Apr-11 & Ethylbenzene & 0.19 & $\mu \mathrm{g} / \mathrm{L}$ & $\mathrm{J}$ & $\mathrm{F}$ & \\
\hline $\mathrm{E}-7$ & 19-Apr-11 & Toluene & 0.41 & $\mu g / L$ & $\mathrm{~J}$ & $\mathrm{~F}$ & \\
\hline E-7 (dup) & 19-Apr-11 & Toluene & 0.42 & $\mu \mathrm{g} / \mathrm{L}$ & $\mathrm{J}$ & $\mathrm{F}$ & \\
\hline $\mathrm{HM}-3$ & 18-Apr-11 & Lead & 0.00083 & $\mathrm{mg} / \mathrm{L}$ & & $\mathrm{F}$ & \\
\hline $\mathrm{HM}-3$ & 18-Apr-11 & Antimony & 0.000054 & $\mathrm{mg} / \mathrm{L}$ & & $\mathrm{F}$ & \\
\hline $\mathrm{HM}-3$ & 18-Apr-11 & Arsenic & 0.00061 & $\mathrm{mg} / \mathrm{L}$ & & $\mathrm{F}$ & \\
\hline $\mathrm{HM}-3$ & 18-Apr-11 & Barium & 0.17 & $\mathrm{mg} / \mathrm{L}$ & & $\mathrm{F}$ & \\
\hline $\mathrm{HM}-3$ & 18-Apr-11 & Beryllium & 0.00025 & $\mathrm{mg} / \mathrm{L}$ & $\mathrm{B}$ & UF & \\
\hline HM-3 & 18-Apr-11 & Chromium & 0.12 & $\mathrm{mg} / \mathrm{L}$ & & $\mathbf{F}$ & 0.1 \\
\hline $\mathrm{HM}-3$ & 18-Apr-11 & Zinc & 0.0086 & $\mathrm{mg} / \mathrm{L}$ & B & $\mathrm{F}$ & \\
\hline $\mathrm{HM}-3$ & 18-Apr-11 & Selenium & 0.000049 & $\mathrm{mg} / \mathrm{L}$ & $B$ & $\mathrm{~F}$ & \\
\hline $\mathrm{HM}-\mathrm{L}$ & 18-Apr-11 & Lead & 0.000013 & $\mathrm{mg} / \mathrm{L}$ & $B$ & FJ & \\
\hline HM-L (dup) & 18-Apr-11 & Lead & 0.00006 & $\mathrm{mg} / \mathrm{L}$ & & $\mathrm{F}$ & \\
\hline $\mathrm{HM}-\mathrm{L}$ & 18-Apr-11 & Antimony & 0.000048 & $\mathrm{mg} / \mathrm{L}$ & & $\mathrm{F}$ & \\
\hline HM-L (dup) & 18-Apr-11 & Antimony & 0.000063 & $\mathrm{mg} / \mathrm{L}$ & & $\mathrm{F}$ & \\
\hline $\mathrm{HM}-\mathrm{L}$ & 18-Apr-11 & Arsenic & 0.0011 & $\mathrm{mg} / \mathrm{L}$ & & $\mathrm{F}$ & \\
\hline HM-L (dup) & 18-Apr-11 & Arsenic & 0.0013 & $\mathrm{mg} / \mathrm{L}$ & & $\mathrm{F}$ & \\
\hline HM-L & 18-Apr-11 & Barium & 0.48 & $\mathrm{mg} / \mathrm{L}$ & & $\mathrm{F}$ & \\
\hline HM-L (dup) & 18-Apr-11 & Barium & 0.49 & $\mathrm{mg} / \mathrm{L}$ & & $\mathrm{F}$ & \\
\hline HM-L (dup) & 18-Apr-11 & Beryllium & 0.00032 & $\mathrm{mg} / \mathrm{L}$ & $\mathrm{B}$ & UF & \\
\hline $\mathrm{HM}-\mathrm{L}$ & 18-Apr-11 & Cadmium & 0.000014 & $\mathrm{mg} / \mathrm{L}$ & $B$ & $\mathrm{~F}$ & \\
\hline HM-L (dup) & 18-Apr-11 & Cadmium & 0.00016 & $\mathrm{mg} / \mathrm{L}$ & & $\mathrm{F}$ & \\
\hline $\mathrm{HM}-\mathrm{L}$ & 18-Apr-11 & Chromium & 0.0012 & $\mathrm{mg} / \mathrm{L}$ & $\mathrm{B}$ & $\mathrm{F}$ & \\
\hline HM-L (dup) & 18-Apr-11 & Chromium & 0.0014 & $\mathrm{mg} / \mathrm{L}$ & $\mathrm{B}$ & UF & \\
\hline HM-L (dup) & 18-Apr-11 & Zinc & 0.0016 & $\mathrm{mg} / \mathrm{L}$ & $\mathrm{B}$ & $\mathrm{FJ}$ & \\
\hline HM-L (dup) & 18-Apr-11 & Selenium & 0.000037 & $\mathrm{mg} / \mathrm{L}$ & $\mathrm{B}$ & $\mathrm{F}$ & \\
\hline HM-L2 & 19-Apr-11 & Antimony & 0.000042 & $\mathrm{mg} / \mathrm{L}$ & & $\mathrm{F}$ & \\
\hline HM-L2 & 19-Apr-11 & Arsenic & 0.000041 & $\mathrm{mg} / \mathrm{L}$ & $\mathrm{B}$ & $\mathrm{F}$ & \\
\hline HM-L2 & 19-Apr-11 & Barium & 0.058 & $\mathrm{mg} / \mathrm{L}$ & & $\mathrm{F}$ & \\
\hline HM-L2 & 19-Apr-11 & Beryllium & 0.00021 & $\mathrm{mg} / \mathrm{L}$ & $\mathrm{B}$ & UF & \\
\hline HM-S & 18-Apr-11 & Benzene & 0.32 & $\mu \mathrm{g} / \mathrm{L}$ & $\mathrm{J}$ & $\mathrm{F}$ & \\
\hline HM-S & 18-Apr-11 & Vinyl chloride & 0.22 & $\mu g / L$ & $\mathrm{~J}$ & $\mathrm{~F}$ & \\
\hline $\mathrm{HM}-\mathrm{S}$ & 18-Apr-11 & Trichloroethene & 1.9 & $\mu \mathrm{g} / \mathrm{L}$ & & $\mathrm{F}$ & \\
\hline $\mathrm{HM}-\mathrm{S}$ & 18-Apr-11 & cis-1,2-Dichloroethene & 6.5 & $\mu \mathrm{g} / \mathrm{L}$ & & $\mathrm{F}$ & \\
\hline $\mathrm{HM}-\mathrm{S}$ & 18-Apr-11 & $\begin{array}{l}\text { trans-1,2- } \\
\text { Dichloroethene }\end{array}$ & 0.83 & $\mu \mathrm{g} / \mathrm{L}$ & $\mathrm{J}$ & $\mathrm{F}$ & \\
\hline $\mathrm{HM}-\mathrm{S}$ & 18-Apr-11 & Arsenic & 0.00011 & $\mathrm{mg} / \mathrm{L}$ & & $\mathrm{F}$ & \\
\hline $\mathrm{HM}-\mathrm{S}$ & 18-Apr-11 & Barium & 0.037 & $\mathrm{mg} / \mathrm{L}$ & & $\mathrm{F}$ & \\
\hline HM-S & 18-Apr-11 & Cadmium & 0.000026 & $\mathrm{mg} / \mathrm{L}$ & B & $\mathrm{F}$ & \\
\hline
\end{tabular}


Table B-2 (continued). Volatile Organic Compounds and Metals that were Detected above the Detection Limit in Groundwater-Samples Collected in April 2011. Results above the MCL or TRG are in Bold.

\begin{tabular}{|c|c|c|c|c|c|c|c|}
\hline Location & $\begin{array}{c}\text { Date } \\
\text { Sampled }\end{array}$ & Analyte & Result & Units & $\begin{array}{c}\text { Lab } \\
\text { Qualifiers }\end{array}$ & $\begin{array}{c}\text { Data } \\
\text { Validation } \\
\text { Qualifiers }\end{array}$ & $\begin{array}{c}\text { MCL or } \\
\text { TRG }\end{array}$ \\
\hline $\mathrm{HMH}-16 \mathrm{R}$ & 20-Apr-11 & Lead & 0.000018 & $\mathrm{mg} / \mathrm{L}$ & $\mathrm{B}$ & FQJ & \\
\hline $\mathrm{HMH}-16 \mathrm{R}$ & 20-Apr-11 & Nickel & 0.0012 & $\mathrm{mg} / \mathrm{L}$ & $\mathrm{B}$ & FQJ & \\
\hline $\mathrm{HMH}-16 \mathrm{R}$ & 20-Apr-11 & Arsenic & 0.00037 & $\mathrm{mg} / \mathrm{L}$ & & $\mathrm{FQ}$ & \\
\hline $\mathrm{HMH}-16 \mathrm{R}$ & 20-Apr-11 & Barium & 0.41 & $\mathrm{mg} / \mathrm{L}$ & & $\mathrm{FQ}$ & \\
\hline $\mathrm{HMH}-16 \mathrm{R}$ & 20-Apr-11 & Cadmium & 0.000021 & $\mathrm{mg} / \mathrm{L}$ & $\mathrm{B}$ & $\mathrm{FQ}$ & \\
\hline $\mathrm{HMH}-16 \mathrm{R}$ & 20-Apr-11 & Selenium & 0.000043 & $\mathrm{mg} / \mathrm{L}$ & $\mathrm{B}$ & $\mathrm{FQ}$ & \\
\hline $\mathrm{HMH}-5 \mathrm{R}$ & 20-Apr-11 & 1,1-Dichloroethene & 0.39 & $\mu g / L$ & $\mathrm{~J}$ & $\mathrm{~F}$ & \\
\hline HMH-5R & 20-Apr-11 & Trichloroethene & 100 & $\mu g / L$ & & $\mathbf{F}$ & 0.005 \\
\hline $\mathrm{HMH}-5 \mathrm{R}$ & 20-Apr-11 & cis-1,2-Dichloroethene & 51 & $\mu \mathrm{g} / \mathrm{L}$ & & $\mathrm{F}$ & \\
\hline $\mathrm{HMH}-5 \mathrm{R}$ & 20-Apr-11 & \begin{tabular}{|l|} 
trans-1,2- \\
Dichloroethene
\end{tabular} & 4.7 & $\mu \mathrm{g} / \mathrm{L}$ & & $\mathrm{F}$ & \\
\hline $\mathrm{HMH}-5 \mathrm{R}$ & 20-Apr-11 & Antimony & 0.000092 & $\mathrm{mg} / \mathrm{L}$ & & $\mathrm{F}$ & \\
\hline $\mathrm{HMH}-5 \mathrm{R}$ & 20-Apr-11 & Arsenic & 0.0022 & $\mathrm{mg} / \mathrm{L}$ & & $\mathrm{F}$ & \\
\hline $\mathrm{HMH}-5 \mathrm{R}$ & 20-Apr-11 & Barium & 0.19 & $\mathrm{mg} / \mathrm{L}$ & & $\mathrm{F}$ & \\
\hline $\mathrm{HMH}-5 \mathrm{R}$ & 20-Apr-11 & Zinc & 0.0021 & $\mathrm{mg} / \mathrm{L}$ & $\mathrm{B}$ & $\mathrm{FJ}$ & \\
\hline $\mathrm{HMH}-5 \mathrm{R}$ & 20-Apr-11 & Selenium & 0.000079 & $\mathrm{mg} / \mathrm{L}$ & $\mathrm{B}$ & $\mathrm{F}$ & \\
\hline SA1-1-H (dup) & 19-Apr-11 & Trichloroethene & 5.6 & $\mu \mathrm{g} / \mathrm{L}$ & & $\mathrm{F}$ & \\
\hline SA1-1-H & 19-Apr-11 & Trichloroethene & 5.6 & $\mu g / L$ & & $\mathbf{F}$ & 0.005 \\
\hline SA1-1-H & 19-Apr-11 & cis-1,2-Dichloroethene & 9.1 & $\mu \mathrm{g} / \mathrm{L}$ & & $\mathrm{F}$ & \\
\hline SA1-1-H (dup) & 19-Apr-11 & cis-1,2-Dichloroethene & 9.2 & $\mu \mathrm{g} / \mathrm{L}$ & & $\mathrm{F}$ & \\
\hline SA1-1-H (dup) & 19-Apr-11 & \begin{tabular}{|l|} 
trans-1,2- \\
Dichloroethene
\end{tabular} & 2.8 & $\mu \mathrm{g} / \mathrm{L}$ & & $\mathrm{F}$ & \\
\hline SA1-1-H & 19-Apr-11 & $\begin{array}{l}\text { trans-1,2- } \\
\text { Dichloroethene }\end{array}$ & 2.8 & $\mu \mathrm{g} / \mathrm{L}$ & & $\mathrm{F}$ & \\
\hline SA1-1-H & 19-Apr-11 & Lead & 0.000011 & $\mathrm{mg} / \mathrm{L}$ & $\mathrm{B}$ & FJ & \\
\hline SA1-1-H & 19-Apr-11 & Nickel & 0.0011 & $\mathrm{mg} / \mathrm{L}$ & $\mathrm{B}$ & $\mathrm{FJ}$ & \\
\hline SA1-1-H & 19-Apr-11 & Antimony & 0.000044 & $\mathrm{mg} / \mathrm{L}$ & & $\mathrm{F}$ & \\
\hline SA1-1-H & 19-Apr-11 & Arsenic & 0.0036 & $\mathrm{mg} / \mathrm{L}$ & & $\mathrm{F}$ & \\
\hline SA1-1-H (dup) & 19-Apr-11 & Arsenic & 0.0038 & $\mathrm{mg} / \mathrm{L}$ & & $\mathrm{F}$ & \\
\hline SA1-1-H (dup) & 19-Apr-11 & Barium & 0.3 & $\mathrm{mg} / \mathrm{L}$ & & $\mathrm{F}$ & \\
\hline SA1-1-H & 19-Apr-11 & Barium & 0.3 & $\mathrm{mg} / \mathrm{L}$ & & $\mathrm{F}$ & \\
\hline SA1-1-H (dup) & 19-Apr-11 & Beryllium & 0.00034 & $\mathrm{mg} / \mathrm{L}$ & $\mathrm{B}$ & UF & \\
\hline SA1-1-H & 19-Apr-11 & Zinc & 0.0042 & $\mathrm{mg} / \mathrm{L}$ & $\mathrm{B}$ & $\mathrm{F}$ & \\
\hline SA1-1-H & 19-Apr-11 & Selenium & 0.000034 & $\mathrm{mg} / \mathrm{L}$ & $\mathrm{B}$ & $\mathrm{F}$ & \\
\hline SA1-1-H (dup) & 19-Apr-11 & Selenium & 0.000075 & $\mathrm{mg} / \mathrm{L}$ & $\mathrm{B}$ & $\mathrm{F}$ & \\
\hline SA1-12-H & 20-Apr-11 & Lead & 0.000029 & $\mathrm{mg} / \mathrm{L}$ & $\mathrm{B}$ & FJ & \\
\hline SA1-12-H & 20-Apr-11 & Arsenic & 0.00016 & $\mathrm{mg} / \mathrm{L}$ & & $\mathrm{F}$ & \\
\hline SA1-12-H & 20-Apr-11 & Barium & 0.32 & $\mathrm{mg} / \mathrm{L}$ & & $\mathrm{F}$ & \\
\hline SA1-12-H & 20-Apr-11 & Cadmium & 0.000019 & $\mathrm{mg} / \mathrm{L}$ & $\mathrm{B}$ & $\mathrm{F}$ & \\
\hline SA1-12-H & 20-Apr-11 & Zinc & 0.0032 & $\mathrm{mg} / \mathrm{L}$ & $\mathrm{B}$ & $\mathrm{F}$ & \\
\hline SA1-2-H & 19-Apr-11 & Benzene & 0.32 & $\mu \mathrm{g} / \mathrm{L}$ & $\mathrm{J}$ & $\mathrm{F}$ & \\
\hline SA1-2-H & 19-Apr-11 & Vinyl chloride & 0.7 & $\mu \mathrm{g} / \mathrm{L}$ & $\mathrm{J}$ & $\mathrm{F}$ & \\
\hline SA1-2-H & 19-Apr-11 & Trichloroethene & 1.5 & $\mu \mathrm{g} / \mathrm{L}$ & & $\mathrm{F}$ & \\
\hline SA1-2-H & 19-Apr-11 & cis-1,2-Dichloroethene & 9.4 & $\mu \mathrm{g} / \mathrm{L}$ & & $\mathrm{F}$ & \\
\hline
\end{tabular}


Table B-2 (continued). Volatile Organic Compounds and Metals that were Detected above the Detection Limit in Groundwater-Samples Collected in April 2011. Results above the MCL or TRG are in Bold.

\begin{tabular}{|c|c|c|c|c|c|c|c|}
\hline Location & $\begin{array}{c}\text { Date } \\
\text { Sampled }\end{array}$ & Analyte & Result & Units & $\begin{array}{c}\text { Lab } \\
\text { Qualifiers }\end{array}$ & $\begin{array}{c}\text { Data } \\
\text { Validation } \\
\text { Qualifiers } \\
\end{array}$ & $\begin{array}{l}\text { MCL or } \\
\text { TRG }\end{array}$ \\
\hline $\mathrm{SA} 1-2-\mathrm{H}$ & 19-Apr-11 & \begin{tabular}{|l|} 
trans-1,2- \\
Dichloroethene
\end{tabular} & 1.8 & $\mu g / L$ & & $\mathrm{~F}$ & \\
\hline SA1-2-H & 19-Apr-11 & Lead & 0.000007 & $\mathrm{mg} / \mathrm{L}$ & $B$ & FJ & \\
\hline SA1-2-H & 19-Apr-11 & Antimony & 0.000025 & $\mathrm{mg} / \mathrm{L}$ & B & $\mathrm{F}$ & \\
\hline SA1-2-H & 19-Apr-11 & Arsenic & 0.0039 & $\mathrm{mg} / \mathrm{L}$ & & $\mathrm{F}$ & \\
\hline SA1-2-H & 19-Apr-11 & Barium & 0.049 & $\mathrm{mg} / \mathrm{L}$ & & $\mathrm{F}$ & \\
\hline SA1-2-H & 19-Apr-11 & Zinc & 0.001 & $\mathrm{mg} / \mathrm{L}$ & $\mathrm{B}$ & FJ & \\
\hline SA1-2-H & 19-Apr-11 & Selenium & 0.000056 & $\mathrm{mg} / \mathrm{L}$ & $\mathrm{B}$ & $\mathrm{F}$ & \\
\hline SA1-3-H & 19-Apr-11 & Benzene & 1.3 & $\mu \mathrm{g} / \mathrm{L}$ & & $\mathrm{F}$ & \\
\hline SA1-3-H & 19-Apr-11 & Vinyl chloride & 1.5 & $\mu \mathrm{g} / \mathrm{L}$ & & $\mathrm{F}$ & \\
\hline SA1-3-H & 19-Apr-11 & 1,1-Dichloroethene & 0.25 & $\mu g / L$ & $\mathrm{~J}$ & $\mathrm{~F}$ & \\
\hline SA1-3-H & 19-Apr-11 & Trichloroethene & 4.1 & $\mu \mathrm{g} / \mathrm{L}$ & & $\mathrm{F}$ & \\
\hline SA1-3-H & 19-Apr-11 & cis-1,2-Dichloroethene & 62 & $\mu \mathrm{g} / \mathrm{L}$ & & $\mathrm{F}$ & \\
\hline SA1-3-H & 19-Apr-11 & \begin{tabular}{|l|} 
trans-1,2- \\
Dichloroethene \\
\end{tabular} & 29 & $\mu \mathrm{g} / \mathrm{L}$ & & $\mathrm{F}$ & \\
\hline SA1-3-H & 19-Apr-11 & Lead & 0.000012 & $\mathrm{mg} / \mathrm{L}$ & $\mathrm{B}$ & $\mathrm{FJ}$ & \\
\hline SA1-3-H & 19-Apr-11 & Antimony & 0.000064 & $\mathrm{mg} / \mathrm{L}$ & & $\mathrm{F}$ & \\
\hline SA1-3-H & 19-Apr-11 & Arsenic & 0.015 & $\mathrm{mg} / \mathrm{L}$ & & $\mathbf{F}$ & 0.01 \\
\hline SA1-3-H & 19-Apr-11 & Barium & 0.08 & $\mathrm{mg} / \mathrm{L}$ & & $\mathrm{F}$ & \\
\hline SA1-3-H & 19-Apr-11 & Chromium & 0.0035 & $\mathrm{mg} / \mathrm{L}$ & $\mathrm{B}$ & $\mathrm{F}$ & \\
\hline SA1-3-H & 19-Apr-11 & Zinc & 0.0057 & $\mathrm{mg} / \mathrm{L}$ & $\mathrm{B}$ & $\mathrm{F}$ & \\
\hline SA1-3-H & 19-Apr-11 & Selenium & 0.00013 & $\mathrm{mg} / \mathrm{L}$ & & $\mathrm{F}$ & \\
\hline SA1-4-H & 19-Apr-11 & Antimony & 0.000033 & $\mathrm{mg} / \mathrm{L}$ & & $\mathrm{F}$ & \\
\hline SA1-4-H & 19-Apr-11 & Arsenic & 0.00038 & $\mathrm{mg} / \mathrm{L}$ & & $\mathrm{F}$ & \\
\hline SA1-4-H & 19-Apr-11 & Barium & 0.29 & $\mathrm{mg} / \mathrm{L}$ & & $\mathrm{F}$ & \\
\hline SA1-4-H & 19-Apr-11 & Zinc & 0.0024 & $\mathrm{mg} / \mathrm{L}$ & $\mathrm{B}$ & $\mathrm{F}$ & \\
\hline SA1-5-H & 19-Apr-11 & cis-1,2-Dichloroethene & 6.8 & $\mu \mathrm{g} / \mathrm{L}$ & & $\mathrm{F}$ & \\
\hline SA1-5-H & 19-Apr-11 & $\begin{array}{l}\text { trans-1,2- } \\
\text { Dichloroethene }\end{array}$ & 1 & $\mu \mathrm{g} / \mathrm{L}$ & & $\mathrm{F}$ & \\
\hline SA1-5-H & 19-Apr-11 & Antimony & 0.000049 & $\mathrm{mg} / \mathrm{L}$ & & $\mathrm{F}$ & \\
\hline SA1-5-H & 19-Apr-11 & Arsenic & 0.00079 & $\mathrm{mg} / \mathrm{L}$ & & $\mathrm{F}$ & \\
\hline SA1-5-H & 19-Apr-11 & Barium & 0.023 & $\mathrm{mg} / \mathrm{L}$ & & $\mathrm{F}$ & \\
\hline SA1-5-H & 19-Apr-11 & Zinc & 0.0041 & $\mathrm{mg} / \mathrm{L}$ & $\mathrm{B}$ & $\mathrm{F}$ & \\
\hline SA1-5-H & 19-Apr-11 & Selenium & 0.0002 & $\mathrm{mg} / \mathrm{L}$ & & $\mathrm{F}$ & \\
\hline SA1-6-H & 20-Apr-11 & Lead & 0.00001 & $\mathrm{mg} / \mathrm{L}$ & B & FJ & \\
\hline SA1-6-H & 20-Apr-11 & Arsenic & 0.000043 & $\mathrm{mg} / \mathrm{L}$ & $\mathrm{B}$ & $\mathrm{F}$ & \\
\hline SA1-6-H & 20-Apr-11 & Barium & 0.023 & $\mathrm{mg} / \mathrm{L}$ & & $\mathrm{F}$ & \\
\hline SA1-6-H & 20-Apr-11 & Cadmium & 0.000032 & $\mathrm{mg} / \mathrm{L}$ & & $\mathrm{F}$ & \\
\hline SA1-6-H & 20-Apr-11 & Zinc & 0.0037 & $\mathrm{mg} / \mathrm{L}$ & B & $\mathrm{F}$ & \\
\hline SA1-6-H & 20-Apr-11 & Selenium & 0.000042 & $\mathrm{mg} / \mathrm{L}$ & $\mathrm{B}$ & $\mathrm{F}$ & \\
\hline SA1-7-H & 20-Apr-11 & Carbon Disulfide & 0.23 & $\mu \mathrm{g} / \mathrm{L}$ & $\mathrm{J}$ & $\mathrm{F}$ & \\
\hline SA1-7-H & 20-Apr-11 & cis-1,2-Dichloroethene & 0.78 & $\mu \mathrm{g} / \mathrm{L}$ & $\mathrm{J}$ & $\mathrm{F}$ & \\
\hline SA1-7-H & 20-Apr-11 & Nickel & 0.0018 & $\mathrm{mg} / \mathrm{L}$ & $B$ & $\mathrm{FJ}$ & \\
\hline SA1-7-H & 20-Apr-11 & Antimony & 0.000014 & $\mathrm{mg} / \mathrm{L}$ & $\mathrm{B}$ & $\mathrm{F}$ & \\
\hline
\end{tabular}


Table B-2 (continued). Volatile Organic Compounds and Metals that were Detected above the Detection Limit in Groundwater-Samples Collected in April 2011. Results above the MCL or TRG are in Bold.

\begin{tabular}{|c|c|c|c|c|c|c|c|}
\hline Location & $\begin{array}{c}\text { Date } \\
\text { Sampled }\end{array}$ & Analyte & Result & Units & $\begin{array}{c}\text { Lab } \\
\text { Qualifiers }\end{array}$ & $\begin{array}{c}\text { Data } \\
\text { Validation } \\
\text { Qualifiers } \\
\end{array}$ & $\begin{array}{l}\text { MCL or } \\
\text { TRG }\end{array}$ \\
\hline SA1-7-H & 20-Apr-11 & Arsenic & 0.011 & $\mathrm{mg} / \mathrm{L}$ & & $\mathbf{F}$ & 0.01 \\
\hline SA1-7-H & 20-Apr-11 & Barium & 0.29 & $\mathrm{mg} / \mathrm{L}$ & & $\mathrm{F}$ & \\
\hline SA1-7-H & 20-Apr-11 & Beryllium & 0.00027 & $\mathrm{mg} / \mathrm{L}$ & $\mathrm{B}$ & UF & \\
\hline SA1-7-H & 20-Apr-11 & Selenium & 0.0011 & $\mathrm{mg} / \mathrm{L}$ & & $\mathrm{F}$ & \\
\hline SA1-8-L & 19-Apr-11 & Lead & 0.000008 & $\mathrm{mg} / \mathrm{L}$ & $\mathrm{B}$ & $\mathrm{F}$ & \\
\hline SA1-8-L & 19-Apr-11 & Arsenic & 0.0037 & $\mathrm{mg} / \mathrm{L}$ & & $\mathrm{F}$ & \\
\hline SA1-8-L & 19-Apr-11 & Barium & 0.23 & $\mathrm{mg} / \mathrm{L}$ & & $\mathrm{F}$ & \\
\hline SA1-8-L & 19-Apr-11 & Zinc & 0.044 & $\mathrm{mg} / \mathrm{L}$ & & $\mathrm{F}$ & \\
\hline SA2-1-L & 18-Apr-11 & Lead & 0.000077 & $\mathrm{mg} / \mathrm{L}$ & & $\mathrm{F}$ & \\
\hline SA2-1-L & 18-Apr-11 & Antimony & 0.00016 & $\mathrm{mg} / \mathrm{L}$ & & $\mathrm{F}$ & \\
\hline SA2-1-L & 18-Apr-11 & Arsenic & 0.0094 & $\mathrm{mg} / \mathrm{L}$ & & $\mathrm{F}$ & \\
\hline SA2-1-L & 18-Apr-11 & Barium & 0.058 & $\mathrm{mg} / \mathrm{L}$ & & $\mathrm{F}$ & \\
\hline SA2-1-L & 18-Apr-11 & Zinc & 0.001 & $\mathrm{mg} / \mathrm{L}$ & $B$ & $\mathrm{FJ}$ & \\
\hline SA2-1-L & 18-Apr-11 & Selenium & 0.00017 & $\mathrm{mg} / \mathrm{L}$ & & $\mathrm{F}$ & \\
\hline SA2-2-L & 18-Apr-11 & Lead & 0.0068 & $\mathrm{mg} / \mathrm{L}$ & & $\mathrm{FQ}$ & \\
\hline SA2-2-L & 18-Apr-11 & Antimony & 0.00045 & $\mathrm{mg} / \mathrm{L}$ & & $\mathrm{FQ}$ & \\
\hline SA2-2-L & 18-Apr-11 & Arsenic & 0.00041 & $\mathrm{mg} / \mathrm{L}$ & & $\mathrm{FQ}$ & \\
\hline SA2-2-L & 18-Apr-11 & Barium & 0.89 & $\mathrm{mg} / \mathrm{L}$ & & $\mathrm{FQ}$ & \\
\hline SA2-2-L & 18-Apr-11 & Beryllium & 0.00043 & $\mathrm{mg} / \mathrm{L}$ & $B$ & UFQ & \\
\hline SA2-2-L & 18-Apr-11 & Chromium & 0.013 & $\mathrm{mg} / \mathrm{L}$ & & $\mathrm{FQ}$ & \\
\hline SA2-2-L & 18-Apr-11 & Zinc & 0.0088 & $\mathrm{mg} / \mathrm{L}$ & $B$ & $\mathrm{FQ}$ & \\
\hline SA2-2-L & 18-Apr-11 & Selenium & 0.00014 & $\mathrm{mg} / \mathrm{L}$ & & $\mathrm{FQ}$ & \\
\hline SA2-4-L & 18-Apr-11 & Lead & 0.000023 & $\mathrm{mg} / \mathrm{L}$ & $B$ & $\mathrm{FJ}$ & \\
\hline SA2-4-L & 18-Apr-11 & Antimony & 0.00006 & $\mathrm{mg} / \mathrm{L}$ & & $\mathrm{F}$ & \\
\hline SA2-4-L & 18-Apr-11 & Arsenic & 0.0093 & $\mathrm{mg} / \mathrm{L}$ & & $\mathrm{F}$ & \\
\hline SA2-4-L & 18-Apr-11 & Barium & 0.11 & $\mathrm{mg} / \mathrm{L}$ & & $\mathrm{F}$ & \\
\hline SA2-4-L & 18-Apr-11 & Beryllium & 0.00021 & $\mathrm{mg} / \mathrm{L}$ & $B$ & UF & \\
\hline SA3-4-H & \begin{tabular}{|l|} 
20-Apr-11 \\
\end{tabular} & Arsenic & 0.00013 & $\mathrm{mg} / \mathrm{L}$ & & $\mathrm{F}$ & \\
\hline SA3-4-H & 20-Apr-11 & Barium & 0.31 & $\mathrm{mg} / \mathrm{L}$ & & $\mathrm{F}$ & \\
\hline SA3-4-H & 20-Apr-11 & Beryllium & 0.00023 & $\mathrm{mg} / \mathrm{L}$ & $B$ & UF & \\
\hline SA3-4-H & 20-Apr-11 & Cadmium & 0.000037 & $\mathrm{mg} / \mathrm{L}$ & & $\mathrm{F}$ & \\
\hline SA3-4-H & 20-Apr-11 & Zinc & 0.0018 & $\mathrm{mg} / \mathrm{L}$ & $\mathrm{B}$ & FJ & \\
\hline SA3-4-H & 20-Apr-11 & Selenium & 0.000058 & $\mathrm{mg} / \mathrm{L}$ & $\mathrm{B}$ & $\mathrm{F}$ & \\
\hline SA4-5-L & 19-Apr-11 & Lead & 0.0055 & $\mathrm{mg} / \mathrm{L}$ & & $\mathrm{FQ}$ & \\
\hline SA4-5-L & 19-Apr-11 & Nickel & 0.0012 & $\mathrm{mg} / \mathrm{L}$ & $B$ & $\mathrm{FQ}$ & \\
\hline SA4-5-L & 19-Apr-11 & Antimony & 0.00023 & $\mathrm{mg} / \mathrm{L}$ & & $\mathrm{FQ}$ & \\
\hline SA4-5-L & 19-Apr-11 & Arsenic & 0.00032 & $\mathrm{mg} / \mathrm{L}$ & & $\mathrm{FQ}$ & \\
\hline SA4-5-L & 19-Apr-11 & Barium & 2.6 & $\mathrm{mg} / \mathrm{L}$ & & $\mathbf{F Q}$ & 2.0 \\
\hline SA4-5-L & 19-Apr-11 & Beryllium & 0.00032 & $\mathrm{mg} / \mathrm{L}$ & B & UFQ & \\
\hline SA4-5-L & 19-Apr-11 & Cadmium & 0.000035 & $\mathrm{mg} / \mathrm{L}$ & & $\mathrm{FQ}$ & \\
\hline SA4-5-L & 19-Apr-11 & Chromium & 0.046 & $\mathrm{mg} / \mathrm{L}$ & & $\mathrm{FQ}$ & \\
\hline SA4-5-L & 19-Apr-11 & Zinc & 0.18 & $\mathrm{mg} / \mathrm{L}$ & & $\mathrm{FQ}$ & \\
\hline SA4-5-L & 19-Apr-11 & Selenium & 0.00023 & $\mathrm{mg} / \mathrm{L}$ & & $\mathrm{FQ}$ & \\
\hline
\end{tabular}


Results shown are greater than the detection limit of 5 times the reported concentration in the method blank

MCL: maximum contaminant level set by the U.S. Environmental Protection Agency

TRG: $\quad$ target remediation goal set by the State of Mississippi

(dup) duplicate sample result

Lab Qualifiers:

$\mathrm{B}$ : If the analyte is inorganic, the result is less than the contract required detection limit.

If the result is organic, the analyte was detected in the method blank.

$\mathrm{J}$ : Estimated-the result is less than the sum of the detection limit plus two times the total propagated uncertainty.

Data Validation Qualifiers:

F: $\quad$ Field sample collected by the low-flow method.

$\mathrm{J}: \quad \quad$ Estimated-the result is less than three times the detection limit.

Q: $\quad$ Qualitative result due to the well characteristics and sample collection method.

$\mathrm{U}$ : Nondetect-the result is less than three times the total propagated uncertainty.

Statistics

165 Results greater than the detection limit

18 Duplicate results

147 Unique results greater than the detection limit

6 Results greater than the MCL or TRG

$6 \quad$ Locations with results greater than the detection limit 
Table B-3. Metals Detected above the Detection Limit in Groundwater Samples Collected in April 2011

\begin{tabular}{|c|c|c|c|c|c|c|c|}
\hline Location & $\begin{array}{c}\text { Date } \\
\text { Sampled }\end{array}$ & Analyte & Result & Units & $\begin{array}{c}\text { Lab } \\
\text { Qualifiers }\end{array}$ & $\begin{array}{c}\text { Data } \\
\text { Validation } \\
\text { Qualifiers }\end{array}$ & $\begin{array}{l}\text { MCL } \\
\text { or } \\
\text { TRG }\end{array}$ \\
\hline Grantham Ck Entry & 18-Apr-11 & Lead & 0.00015 & $\mathrm{mg} / \mathrm{L}$ & & & \\
\hline Grantham Ck Entry & 18-Apr-11 & Arsenic & 0.00026 & $\mathrm{mg} / \mathrm{L}$ & & & \\
\hline Grantham Ck Entry & 18-Apr-11 & Barium & 0.029 & $\mathrm{mg} / \mathrm{L}$ & & & \\
\hline Grantham Ck Entry & 18-Apr-11 & Zinc & 0.0026 & $\mathrm{mg} / \mathrm{L}$ & $\mathrm{B}$ & $\mathrm{J}$ & \\
\hline Grantham Ck Entry & 18-Apr-11 & Selenium & 0.000043 & $\mathrm{mg} / \mathrm{L}$ & $B$ & & \\
\hline HALFMOON CREEK & 18-Apr-11 & Lead & 0.000085 & $\mathrm{mg} / \mathrm{L}$ & & & \\
\hline HALFMOON CREEK & 18-Apr-11 & Arsenic & 0.00022 & $\mathrm{mg} / \mathrm{L}$ & & & \\
\hline HALFMOON CREEK & 18-Apr-11 & Barium & 0.029 & $\mathrm{mg} / \mathrm{L}$ & & & \\
\hline HALFMOON CREEK & 18-Apr-11 & Selenium & 0.000047 & $\mathrm{mg} / \mathrm{L}$ & $\mathrm{B}$ & & \\
\hline HALFMOONCRKOVERFLOW & 18-Apr-11 & Lead & 0.0002 & $\mathrm{mg} / \mathrm{L}$ & & & \\
\hline HALFMOONCRKOVERFLOW & 18-Apr-11 & Mercury & 0.000019 & $\mathrm{mg} / \mathrm{L}$ & $\mathrm{B}$ & & \\
\hline HALFMOONCRKOVERFLOW & 18-Apr-11 & Antimony & 0.00028 & $\mathrm{mg} / \mathrm{L}$ & & & \\
\hline HALFMOONCRKOVERFLOW & 18-Apr-11 & Arsenic & 0.00086 & $\mathrm{mg} / \mathrm{L}$ & & & \\
\hline HALFMOONCRKOVERFLOW & 18-Apr-11 & Barium & 0.098 & $\mathrm{mg} / \mathrm{L}$ & & & \\
\hline HALFMOONCRKOVERFLOW & 18-Apr-11 & Cadmium & 0.000017 & $\mathrm{mg} / \mathrm{L}$ & $\mathrm{B}$ & & \\
\hline HALFMOONCRKOVERFLOW & 18-Apr-11 & Chromium & 0.0021 & $\mathrm{mg} / \mathrm{L}$ & $\mathrm{B}$ & $\mathrm{J}$ & \\
\hline HALFMOONCRKOVERFLOW & 18-Apr-11 & Zinc & 0.0066 & $\mathrm{mg} / \mathrm{L}$ & $\mathrm{B}$ & & \\
\hline HALFMOONCRKOVERFLOW & 18-Apr-11 & Selenium & 0.00019 & $\mathrm{mg} / \mathrm{L}$ & & & \\
\hline Half Moon Ck Entry & 19-Apr-11 & Lead & 0.00013 & $\mathrm{mg} / \mathrm{L}$ & & & \\
\hline Half Moon Ck Entry & 19-Apr-11 & Antimony & 0.000016 & $\mathrm{mg} / \mathrm{L}$ & $\mathrm{B}$ & & \\
\hline Half Moon Ck Entry & 19-Apr-11 & Arsenic & 0.00018 & $\mathrm{mg} / \mathrm{L}$ & & & \\
\hline Half Moon Ck Entry & 19-Apr-11 & Barium & 0.034 & $\mathrm{mg} / \mathrm{L}$ & & & \\
\hline Half Moon Ck Entry & 19-Apr-11 & Cadmium & 0.000014 & $\mathrm{mg} / \mathrm{L}$ & $B$ & & \\
\hline Half Moon Ck Entry & 19-Apr-11 & Zinc & 0.0056 & $\mathrm{mg} / \mathrm{L}$ & $\mathrm{B}$ & & \\
\hline Half Moon Ck Entry & 19-Apr-11 & Selenium & 0.000048 & $\mathrm{mg} / \mathrm{L}$ & $\mathrm{B}$ & & \\
\hline Half Moon Ck Exit & 18-Apr-11 & Lead & 0.000085 & $\mathrm{mg} / \mathrm{L}$ & & & \\
\hline Half Moon Ck Exit & 18-Apr-11 & Mercury & 0.00001 & $\mathrm{mg} / \mathrm{L}$ & $B$ & & \\
\hline Half Moon Ck Exit & 18-Apr-11 & Arsenic & 0.0002 & $\mathrm{mg} / \mathrm{L}$ & & & \\
\hline Half Moon Ck Exit & 18-Apr-11 & Barium & 0.027 & $\mathrm{mg} / \mathrm{L}$ & & & \\
\hline Half Moon Ck Exit & 18-Apr-11 & Zinc & 0.0018 & $\mathrm{mg} / \mathrm{L}$ & $\mathrm{B}$ & $\mathrm{J}$ & \\
\hline Hick Hollow Ck Entry & 18-Apr-11 & Lead & 0.000043 & $\mathrm{mg} / \mathrm{L}$ & $B$ & & \\
\hline Hick Hollow Ck Entry & 18-Apr-11 & Arsenic & 0.00015 & $\mathrm{mg} / \mathrm{L}$ & & & \\
\hline Hick Hollow Ck Entry & 18-Apr-11 & Barium & 0.028 & $\mathrm{mg} / \mathrm{L}$ & & & \\
\hline Hick Hollow Ck Entry & 18-Apr-11 & Zinc & 0.0012 & $\mathrm{mg} / \mathrm{L}$ & $\mathrm{B}$ & $\mathrm{J}$ & \\
\hline HickHCrTSD-East & 18-Apr-11 & Lead & 0.000054 & $\mathrm{mg} / \mathrm{L}$ & & & \\
\hline HickHCrTSD-East & 18-Apr-11 & Antimony & 0.000014 & $\mathrm{mg} / \mathrm{L}$ & $\mathrm{B}$ & & \\
\hline HickHCrTSD-East & 18-Apr-11 & Arsenic & 0.00016 & $\mathrm{mg} / \mathrm{L}$ & & & \\
\hline HickHCrTSD-East & 18-Apr-11 & Barium & 0.034 & $\mathrm{mg} / \mathrm{L}$ & & & \\
\hline HickHCrTSD-East & 18-Apr-11 & Cadmium & 0.00002 & $\mathrm{mg} / \mathrm{L}$ & $B$ & & \\
\hline HickHCrTSD-East & 18-Apr-11 & Zinc & 0.005 & $\mathrm{mg} / \mathrm{L}$ & $B$ & & \\
\hline Pond West of GZ & 18-Apr-11 & Lead & 0.00092 & $\mathrm{mg} / \mathrm{L}$ & & & \\
\hline Pond West of GZ & 18-Apr-11 & Mercury & 0.000017 & $\mathrm{mg} / \mathrm{L}$ & $\mathrm{B}$ & & \\
\hline Pond West of GZ & 18-Apr-11 & Nickel & 0.0011 & $\mathrm{mg} / \mathrm{L}$ & $\mathrm{B}$ & $\mathrm{J}$ & \\
\hline Pond West of GZ & 18-Apr-11 & Antimony & 0.00059 & $\mathrm{mg} / \mathrm{L}$ & & & \\
\hline Pond West of GZ & 18-Apr-11 & Arsenic & 0.0028 & $\mathrm{mg} / \mathrm{L}$ & & & \\
\hline Pond West of GZ & 18-Apr-11 & Barium & 0.085 & $\mathrm{mg} / \mathrm{L}$ & & & \\
\hline Pond West of GZ & 18-Apr-11 & Cadmium & 0.000066 & $\mathrm{mg} / \mathrm{L}$ & & & \\
\hline Pond West of GZ & 18-Apr-11 & Chromium & 0.0019 & $\mathrm{mg} / \mathrm{L}$ & $B$ & $\mathrm{~J}$ & \\
\hline Pond West of GZ & 18-Apr-11 & Zinc & 0.014 & $\mathrm{mg} / \mathrm{L}$ & $B$ & & \\
\hline Pond West of GZ & 18-Apr-11 & Selenium & 0.00022 & $\mathrm{mg} / \mathrm{L}$ & & & \\
\hline Reeco Pit (A) & 18-Apr-11 & Lead & 0.0011 & $\mathrm{mg} / \mathrm{L}$ & & & \\
\hline
\end{tabular}


Table B-3 (continued). Metals Detected above the Detection Limit in Groundwater-Samples Collected in April 2011

\begin{tabular}{||l|c|l|l|l|c|c|c||}
\hline \multicolumn{1}{||}{ Location } & $\begin{array}{c}\text { Date } \\
\text { Sampled }\end{array}$ & Analyte & Result & Units & $\begin{array}{c}\text { Lab } \\
\text { Qualifiers }\end{array}$ & $\begin{array}{c}\text { Data } \\
\text { Validation } \\
\text { Qualifiers }\end{array}$ & $\begin{array}{c}\text { MCL } \\
\text { or } \\
\text { TRG }\end{array}$ \\
\hline Reeco Pit (A) & $18-A p r-11$ & Mercury & 0.000017 & $\mathrm{mg} / \mathrm{L}$ & $\mathrm{B}$ & & \\
\hline Reeco Pit (A) & $18-\mathrm{Apr}-11$ & Nickel & 0.0028 & $\mathrm{mg} / \mathrm{L}$ & $\mathrm{B}$ & $\mathrm{J}$ & \\
\hline Reeco Pit (A) & $18-\mathrm{Apr}-11$ & Antimony & 0.00086 & $\mathrm{mg} / \mathrm{L}$ & & & \\
\hline Reeco Pit (A) & $18-\mathrm{Apr}-11$ & Arsenic & 0.0018 & $\mathrm{mg} / \mathrm{L}$ & & & \\
\hline Reeco Pit (A) & $18-\mathrm{Apr}-11$ & Barium & 0.035 & $\mathrm{mg} / \mathrm{L}$ & & & \\
\hline Reeco Pit (A) & $18-\mathrm{Apr}-11$ & Chromium & 0.0046 & $\mathrm{mg} / \mathrm{L}$ & $\mathrm{B}$ & & \\
\hline Reeco Pit (A) & $18-\mathrm{Apr}-11$ & Zinc & 0.011 & $\mathrm{mg} / \mathrm{L}$ & $\mathrm{B}$ & & \\
\hline Reeco Pit (A) & $18-\mathrm{Apr}-11$ & Selenium & 0.00014 & $\mathrm{mg} / \mathrm{L}$ & & & \\
\hline
\end{tabular}

Lab Qualifiers:

B: If the analyte is inorganic, the result is less than the contract required detection limit.

Data Validation Qualifiers

$\mathrm{J}: \quad$ Estimated-the result is less than three times the detection limit.

Statistics

$59 \quad$ Results greater than the detection limit

$0 \quad$ Duplicate results

$59 \quad$ Unique results greater than the detection limit

0 Results greater than the MCL or TRG 
Appendix C

\section{Concentration Trend Plots}


This page intentionally left blank 


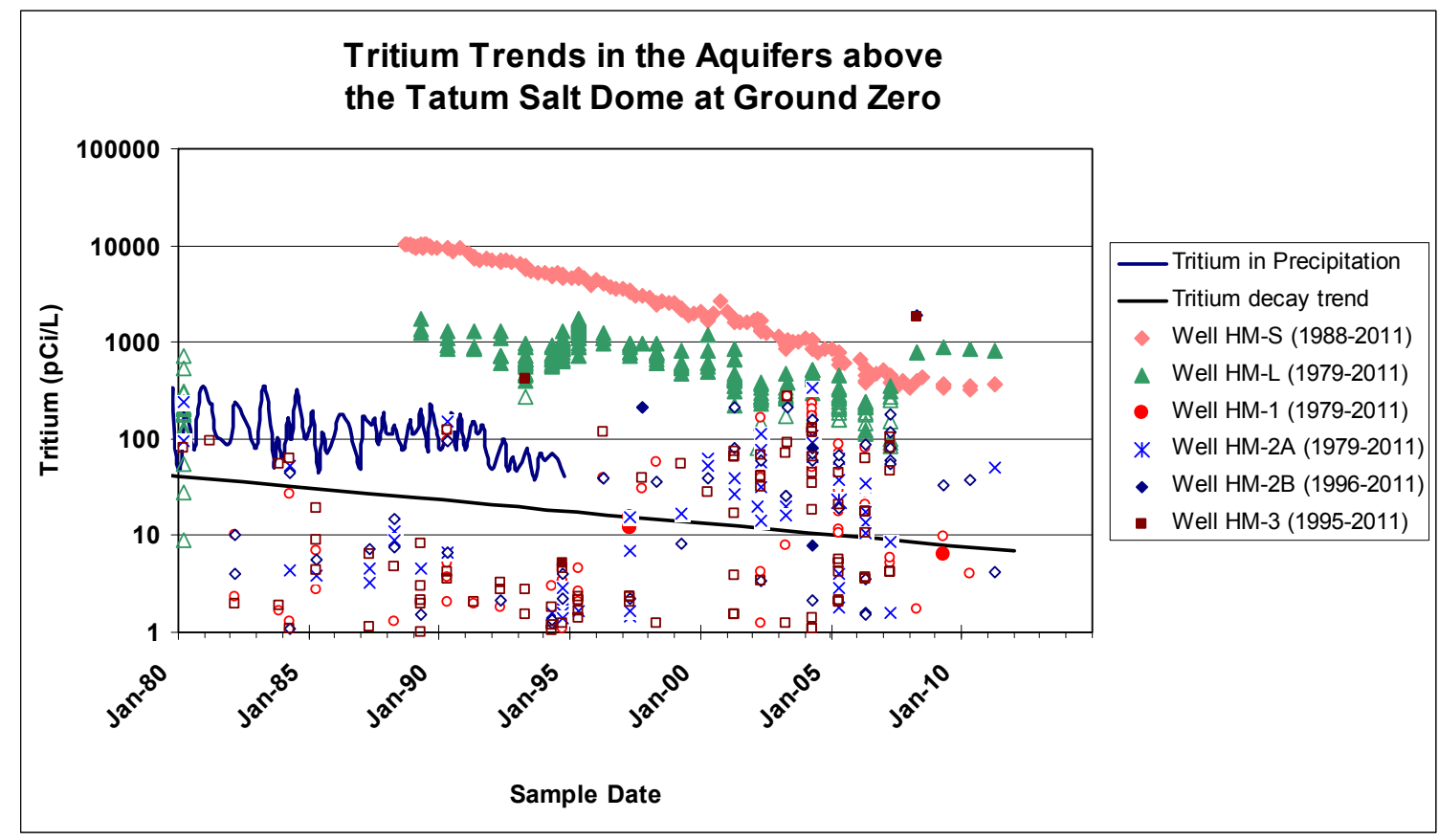

Figure $C-1$. Tritium concentration trends (in $p C i / L$ ) detected in aquifers above the Tatum Salt Dome plotted through 2011. The legend lists wells by increasing depth below the surface starting with the Alluvial Aquifer, the shallowest aquifer. A plotted hollow symbol (and " $x$ ", for well HM-2A) represents a non-quantitative value - the value is less than the tritium MDC. The same symbol shown solid (and "+" superimposed on " $x$ ", for well $H M-2 A$ ) designates a tritium concentration greater than the MDC. The April 2008 tritium concentrations detected in well HM-3 and HM-2B (obscured) are outliers.

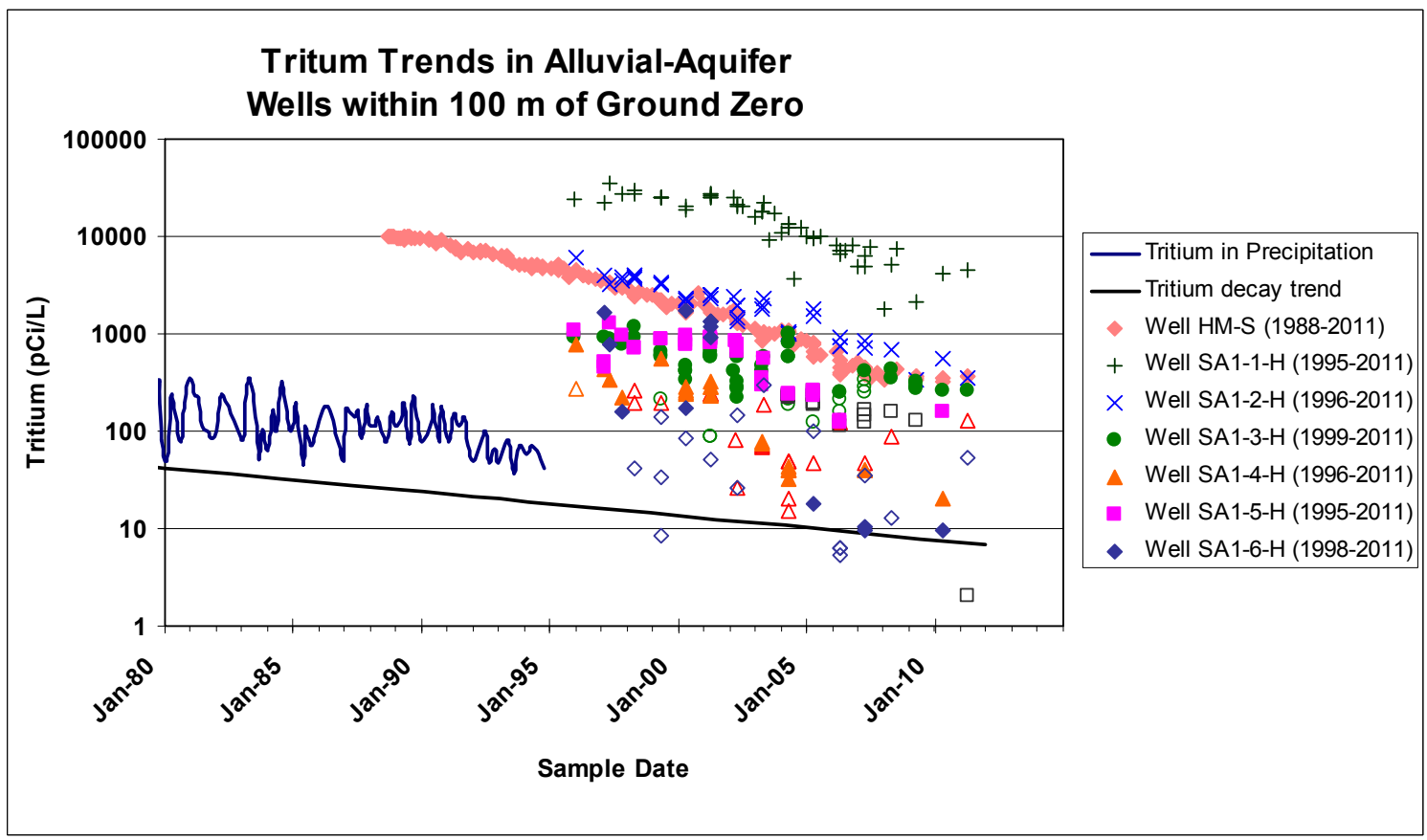

Figure $C-2$. Tritium concentration trends (in $\mathrm{pCi} / \mathrm{L}$ ) detected in seven groundwater wells in the Alluvial Aquifer plotted through 2011. The wells are within 100 meters of ground zero. A plotted hollow symbol represents a non-quantitative value-the value is less than the tritium MDC. The same symbol shown solid designates a tritium concentration greater than the MDC. All tritium concentrations detected in wells SA1-1-H and SA1-2-H are quantitative and designated by point symbols "+" and " $x$ ", respectively. 


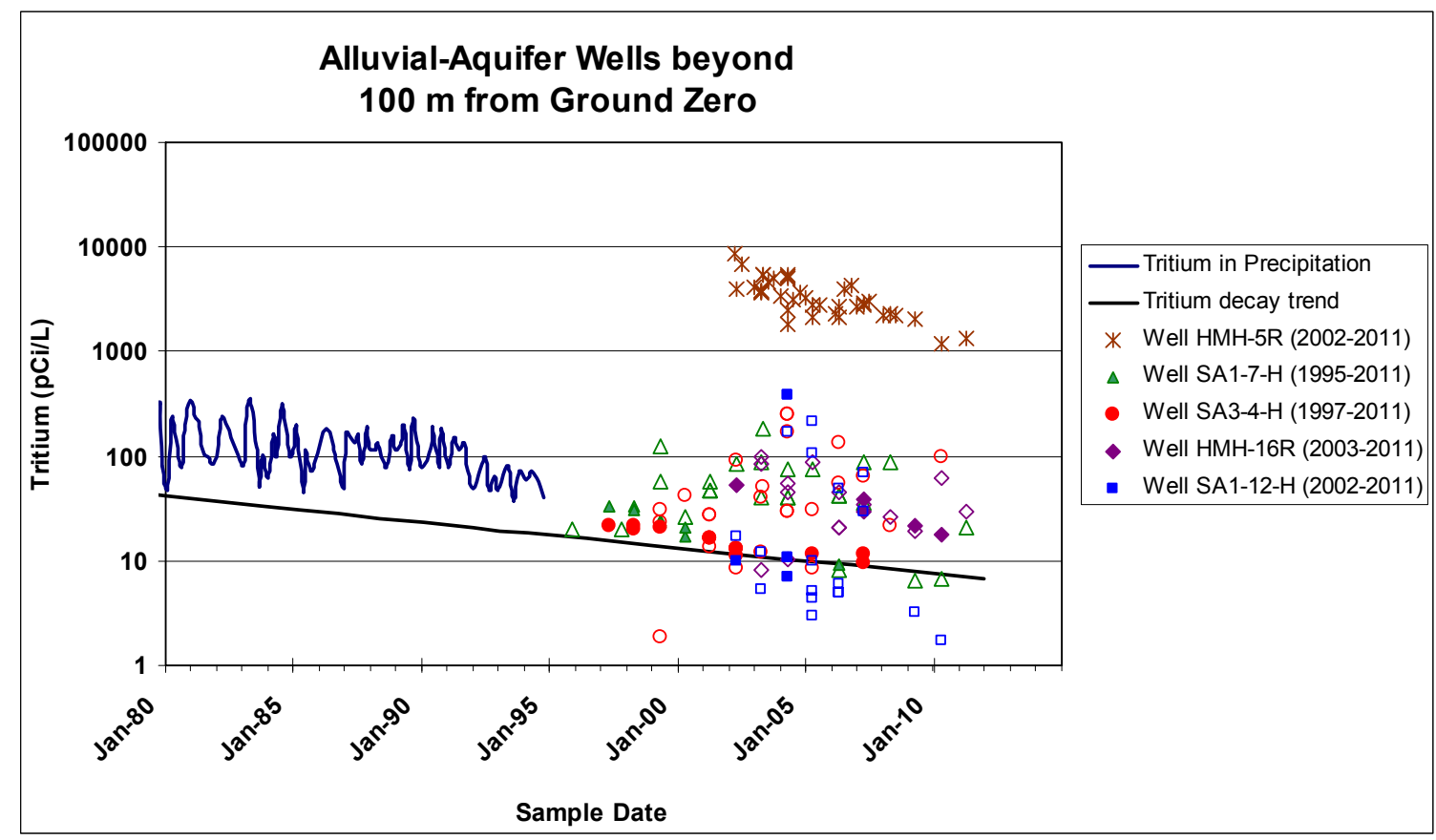

Figure C-3. Tritium concentration trends (in $\mathrm{pCi} / \mathrm{L}$ ) detected in Alluvial-Aquifer wells that are beyond 100 meters from ground zero plotted through 2011. The wells are ordered in the legend (top-to-bottom) by increasing distance from ground zero. A plotted hollow symbol represents a non-quantitative valuethe value is less than the tritium MDC. The same symbol shown solid designates a tritium concentration greater than the MDC. All tritium results detected in well HMH-5R groundwater are quantitative.

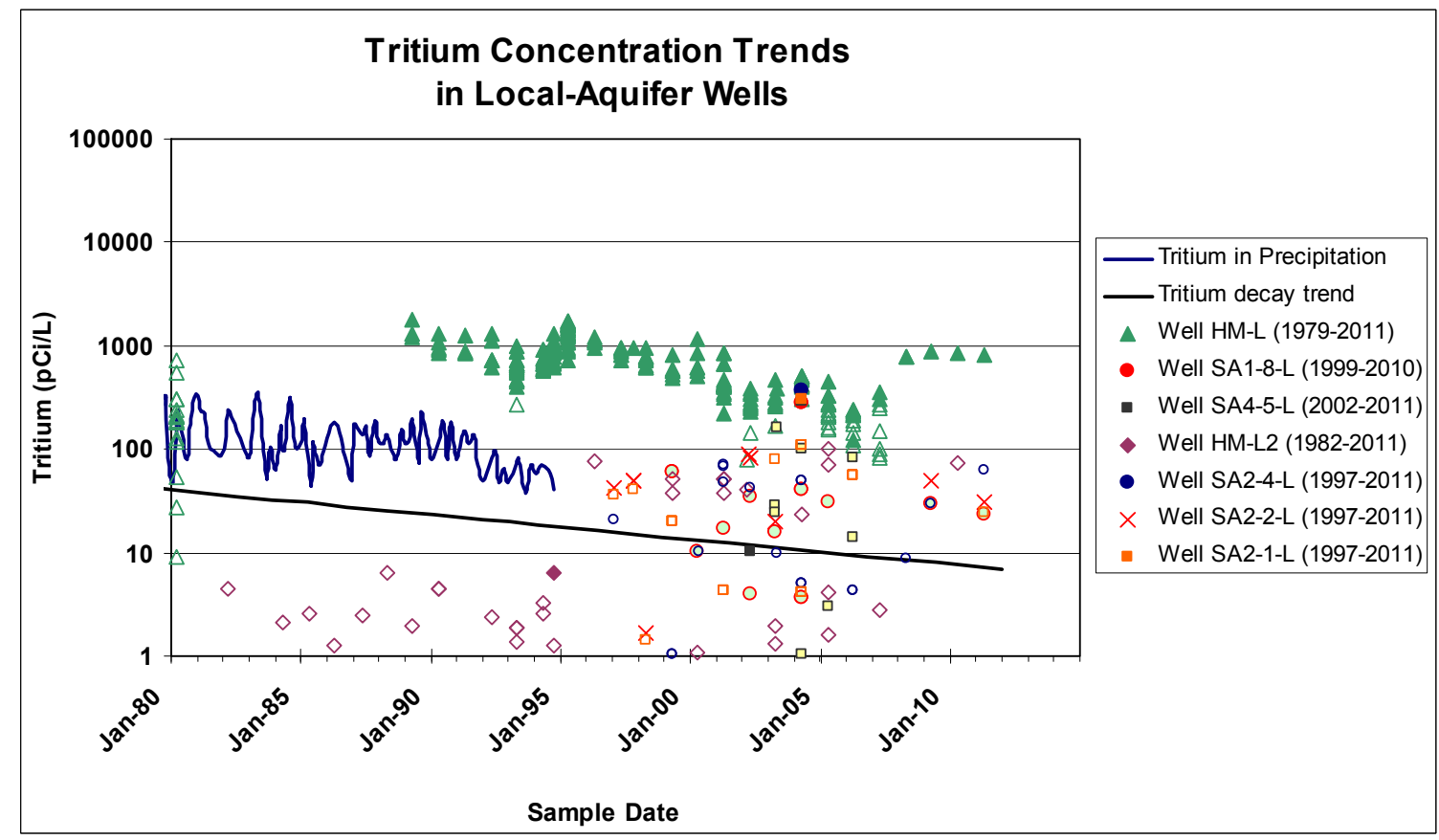

Figure $\mathrm{C}-4$. Tritium concentration trends (in $\mathrm{pCi} / \mathrm{L}$ ) detected in the seven wells that monitor the Local Aquifer plotted through 2011. A plotted hollow symbol (and " $x$ ", for well SA2-2-L) represents a non-quantitative value-the value is less than the tritium MDC. The same symbol shown solid designates a quantitative tritium concentration. There are no values greater than the MDC in well SA2-2-L. 


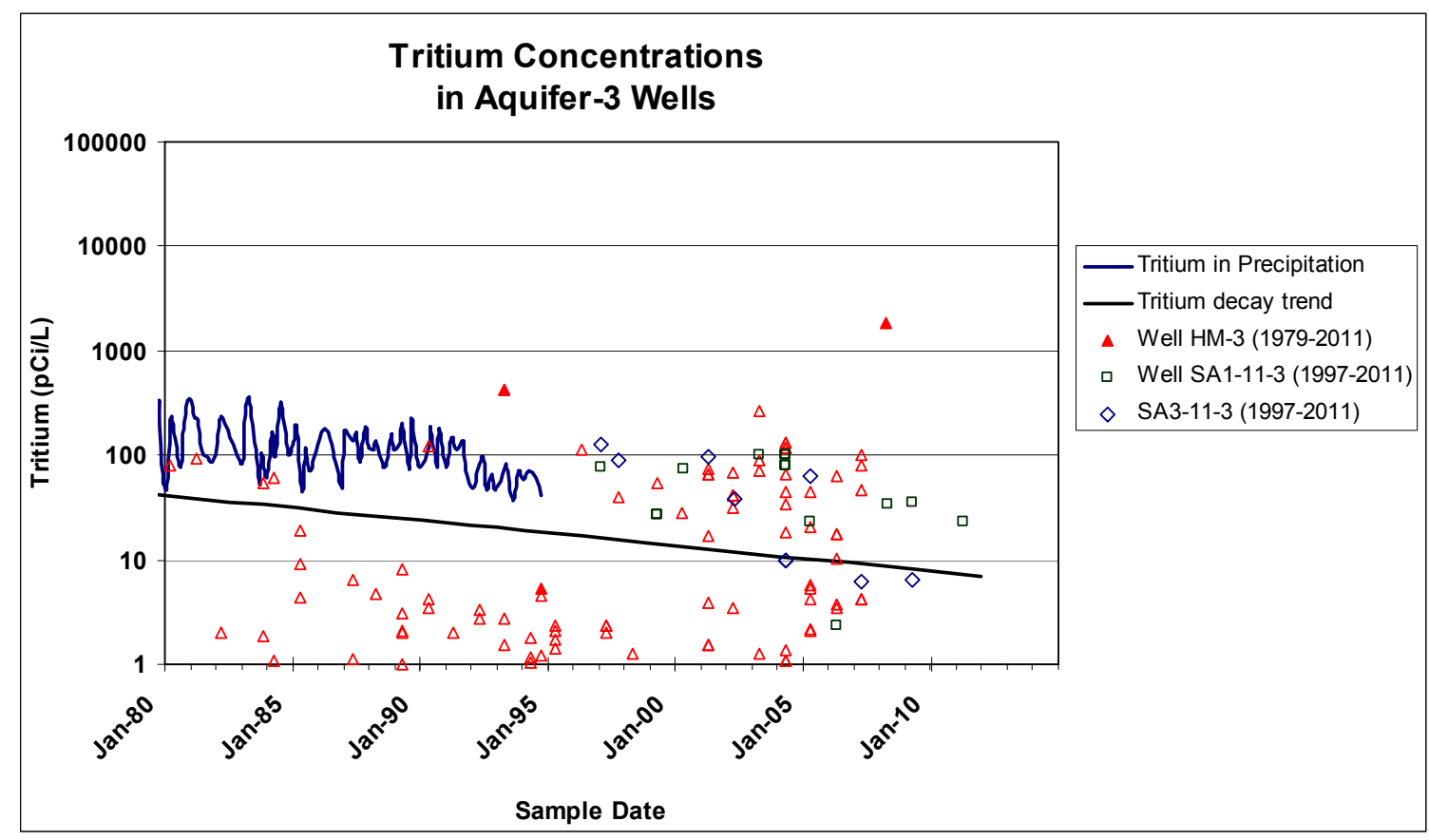

Figure $C-5$.Tritium concentrations (in $p C i / L$ ) detected in three wells that monitor Aquifer 3 plotted through 2011. Except for three values from well HM-3, all results plotted are not quantitative-the values are less than the tritium MDC.

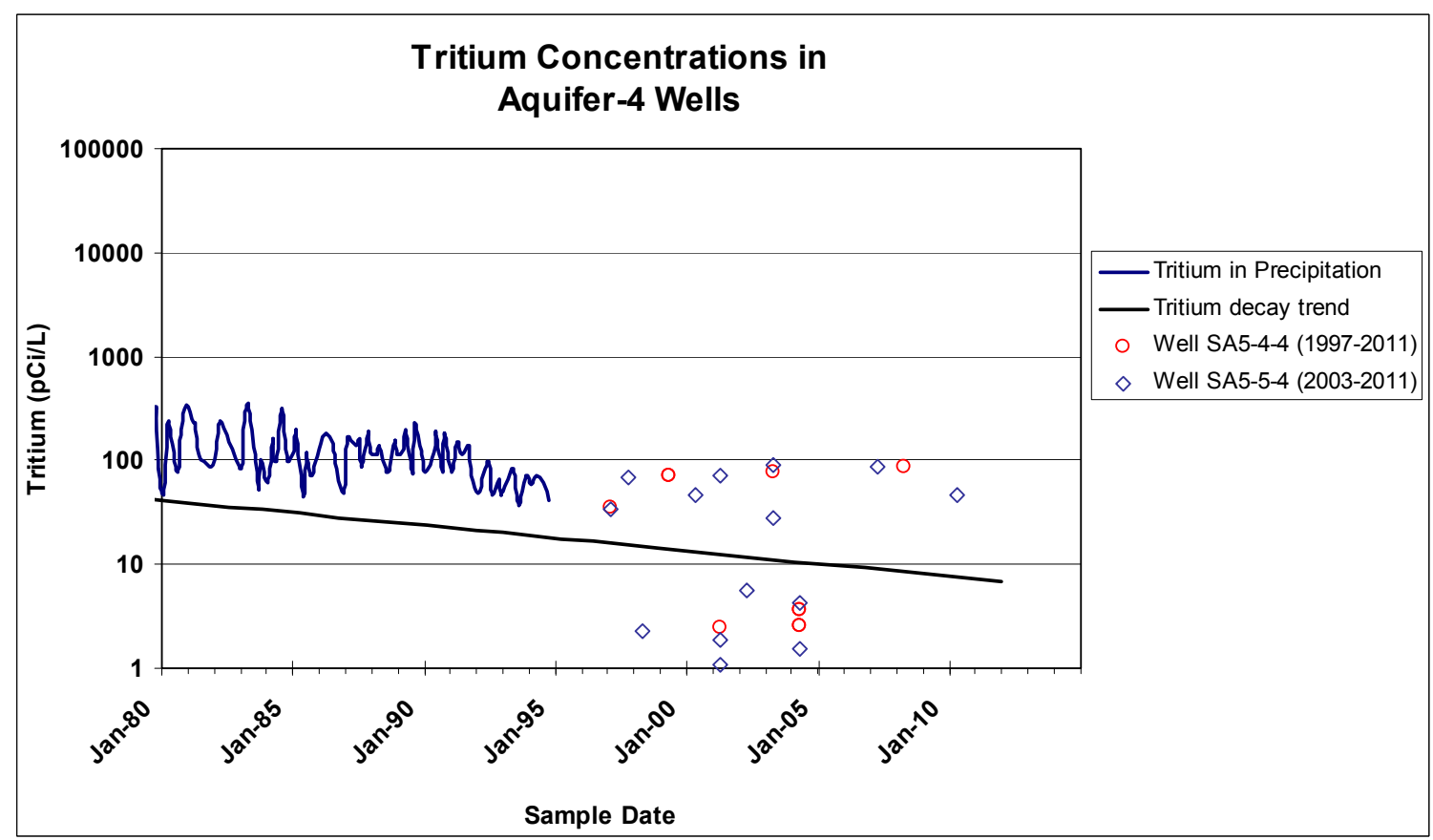

Figure C-6. Tritium concentrations (in $\mathrm{pCi} / \mathrm{L}$ ) detected in two wells in Aquifer 4 plotted through 2011. The plotted results are not quantitative_the values are less than the tritium MDC. 


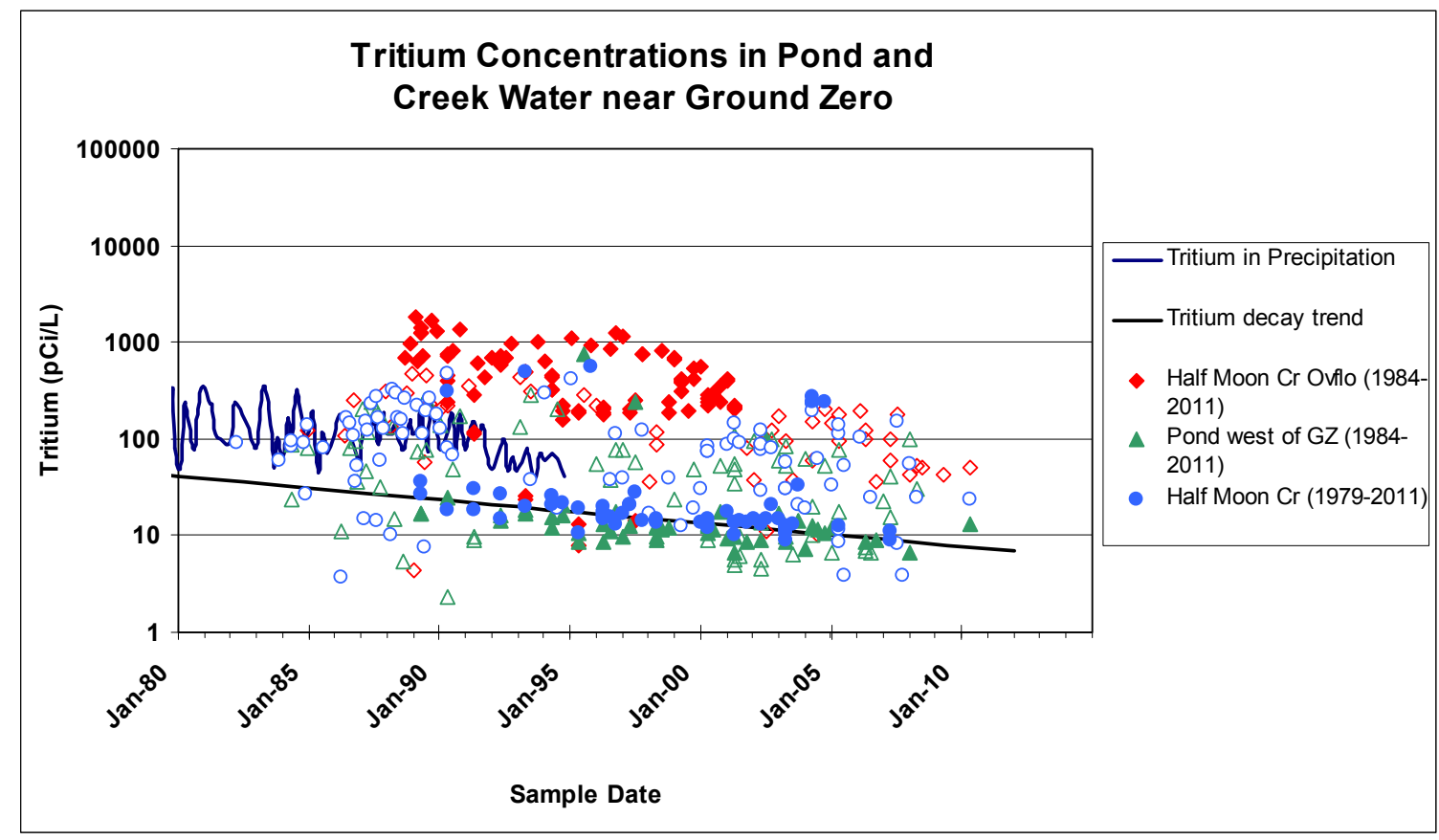

Figure C-7. Tritium concentrations (in $\mathrm{pCi} / \mathrm{L}$ ) detected in surface samples collected from ponds near ground zero and Half Moon Creek, downstream from ground zero. A plotted hollow symbol represents a non-quantitative value-the value is less than the tritium MDC. The same symbol shown solid designates a tritium concentration greater than the MDC.

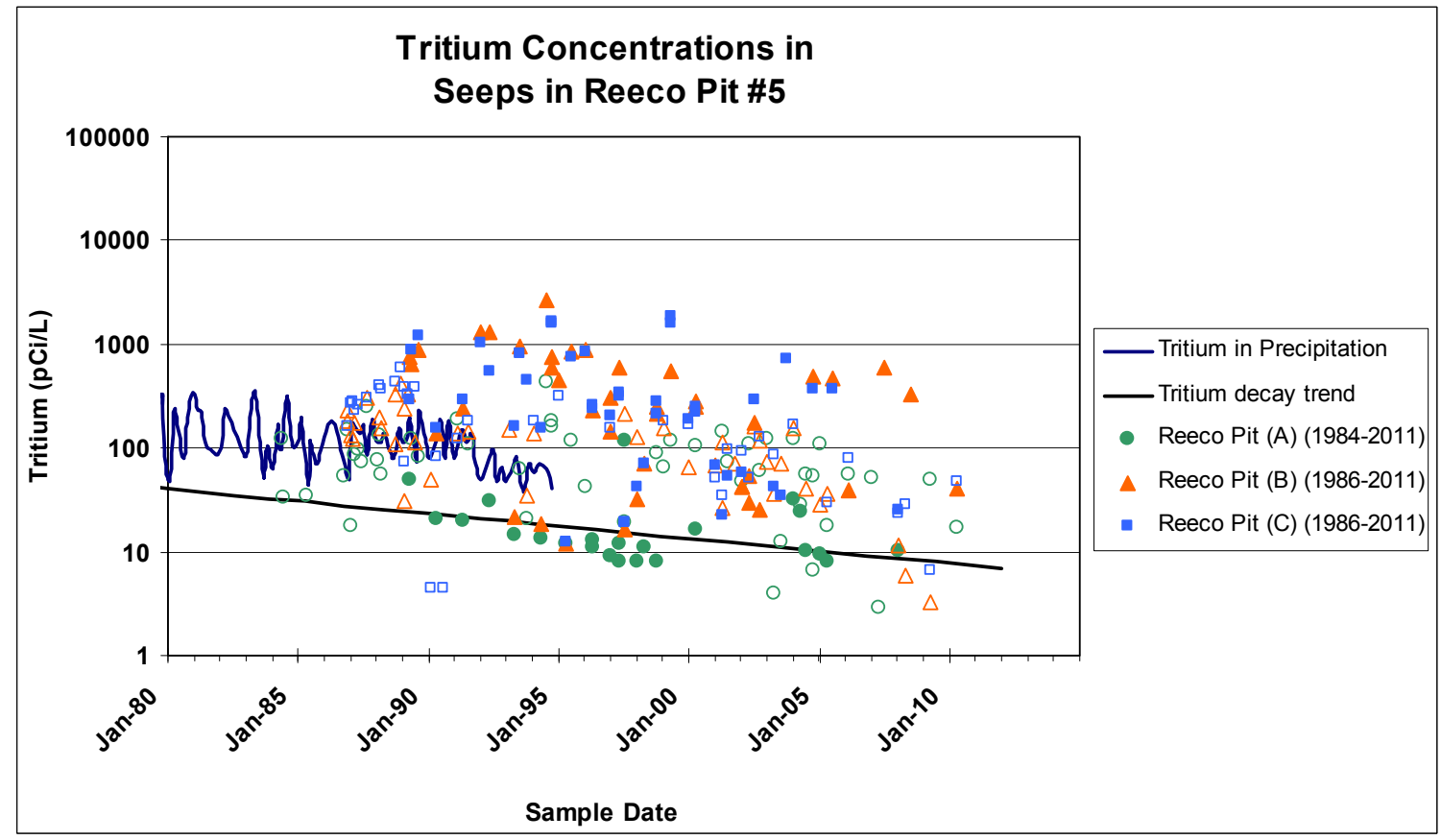

Figure $C-8$. Tritium concentration (in $\mathrm{pCi} / \mathrm{L}$ ) detected in water samples collected from seeps in the area of Reeco Pit \#5 are plotted through 2011. A plotted hollow symbol represents a non-quantitative value-the value is less than the tritium MDC. The same symbol shown solid designates a tritium concentration greater than the MDC. In April 2011, the seeps at (B) and (C) were dry; the laboratory reported zero for $(A)$. 


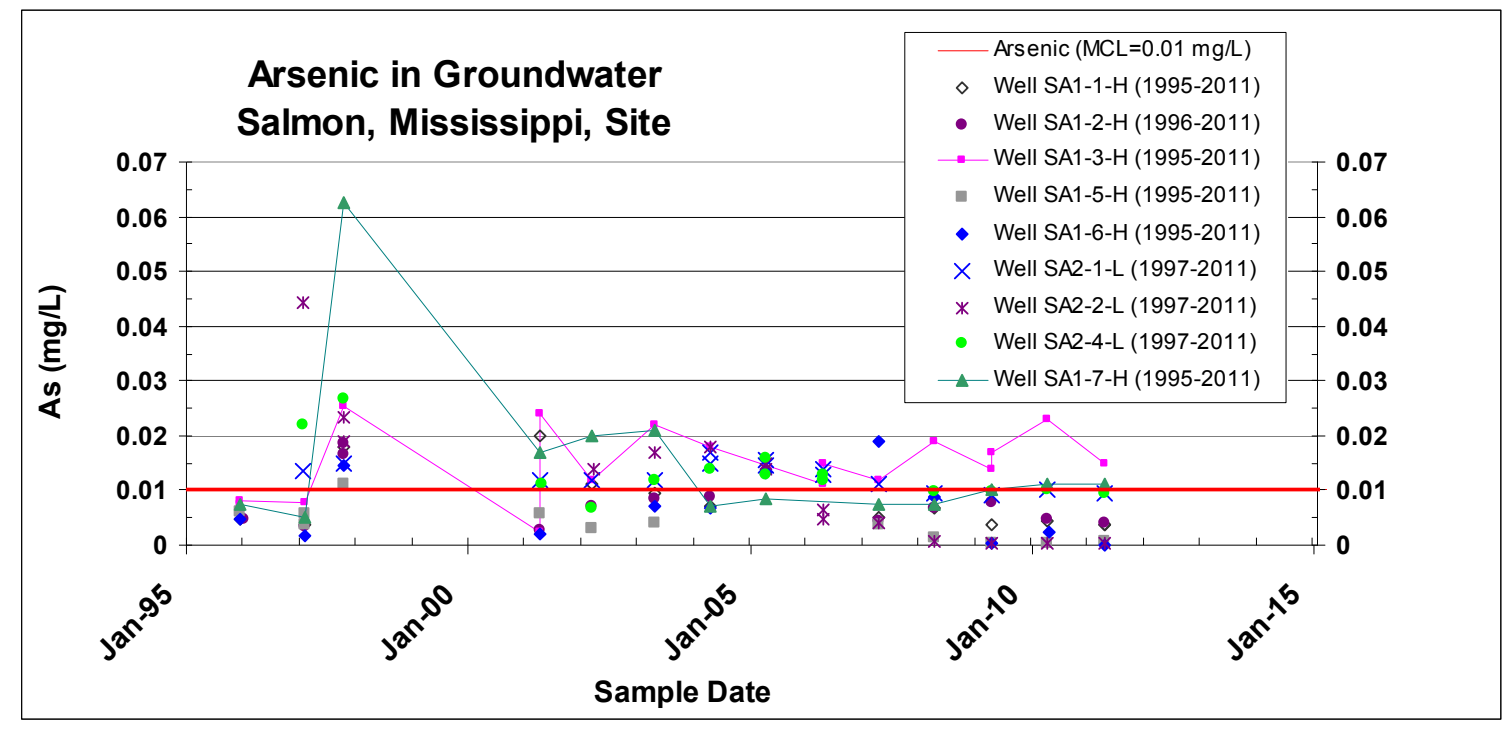

Figure C-9. Arsenic detected in groundwater collected from onsite wells. Only data that has exceeded the $M C L$ at least once during the period is plotted. A line is drawn through the groundwater well data to indicate the arsenic concentration exceeded the MCL in 2011. Well names ending in " $H$ " are in the Alluvial Aquifer; wells ending in " $L$ " are in the Local Aquifer.

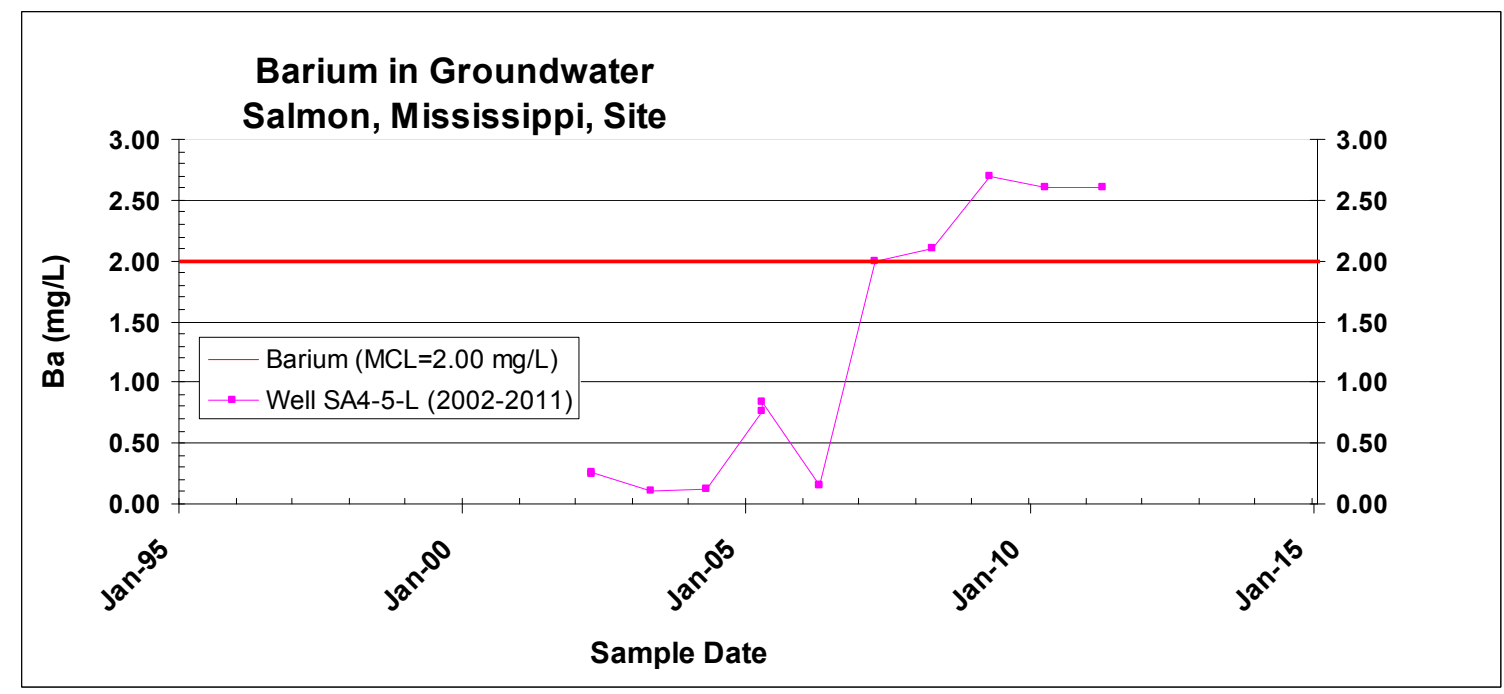

Figure C-10. Barium detected in groundwater collected from well SA4-5-L. This is the only well in which barium has been detected above the barium MCL. 


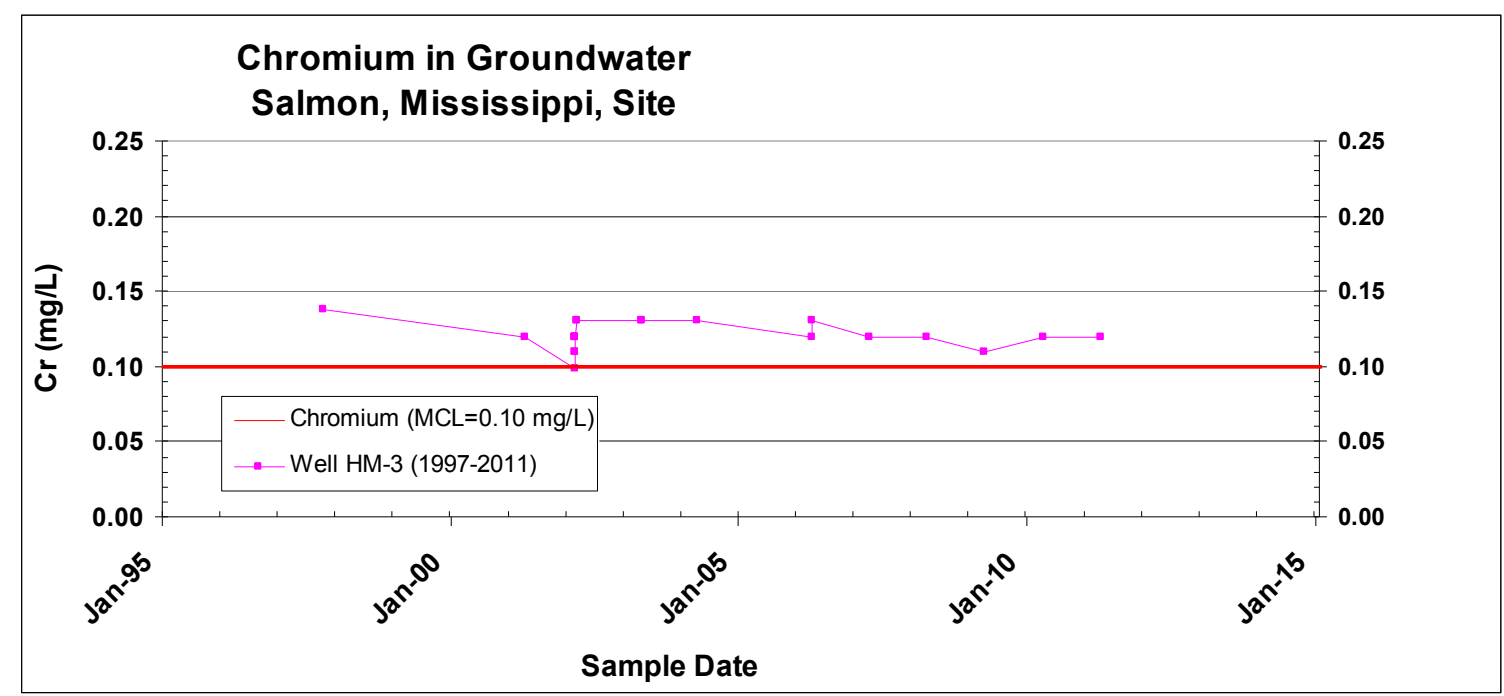

Figure C-11. Chromium detected in groundwater since 1997. Only chromium data that have exceeded the MCL at least once are plotted. Prior to 1997, the laboratory's detection limit for chromium was greater than the MCL.

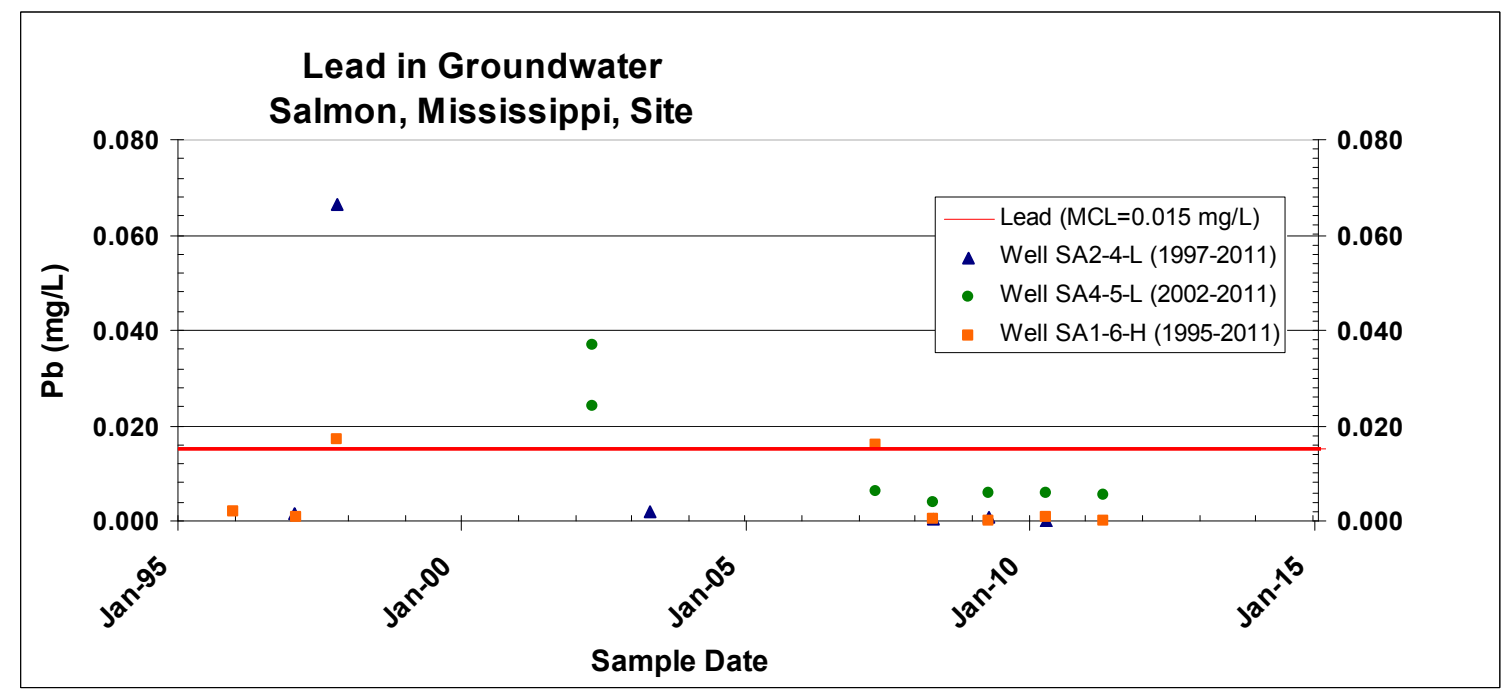

Figure C-12. Lead detected in groundwater since 1995. Only data that have exceeded the MCL at least once during the period are plotted. 


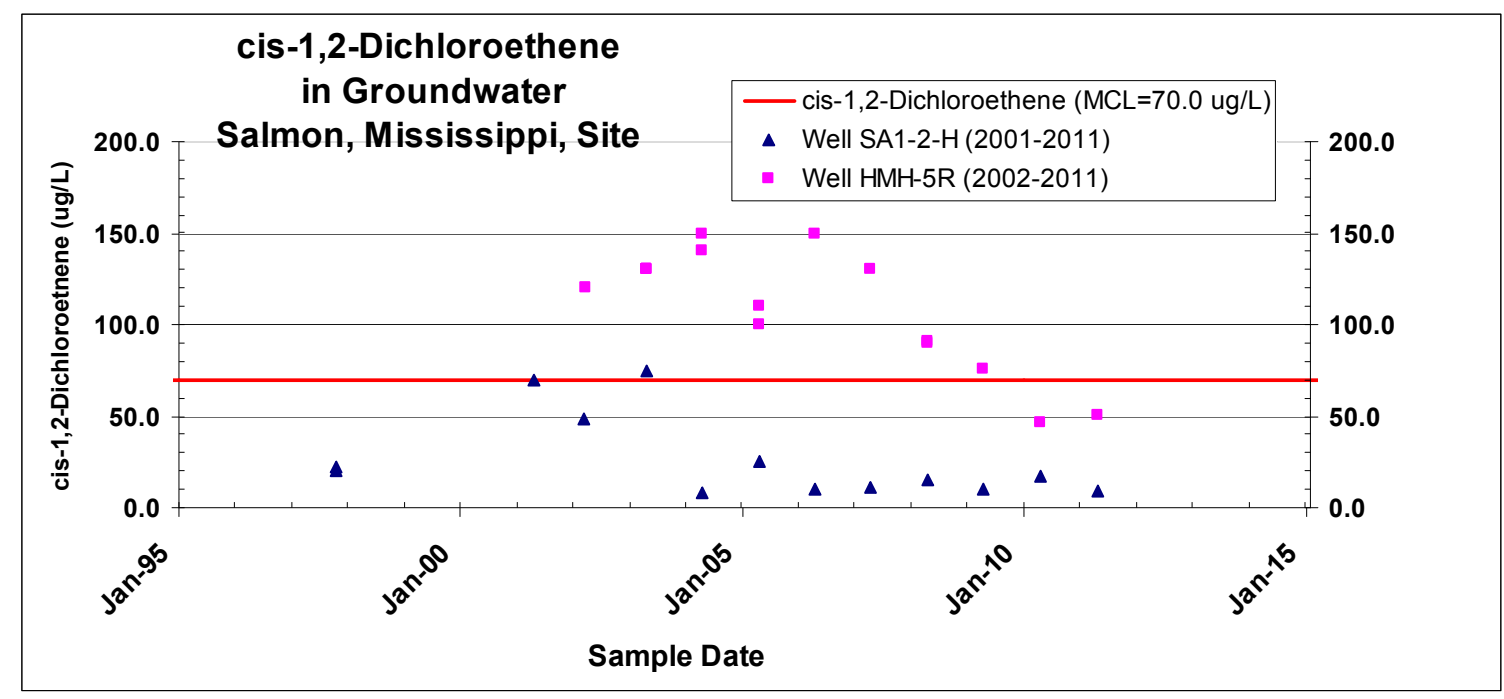

Figure C-13. cis-1,2,-Dichloroethene detected in groundwater collected from wells in the Alluvial Aquifer since 2002. Only data that have exceeded the MCL at least once during the period are plotted.

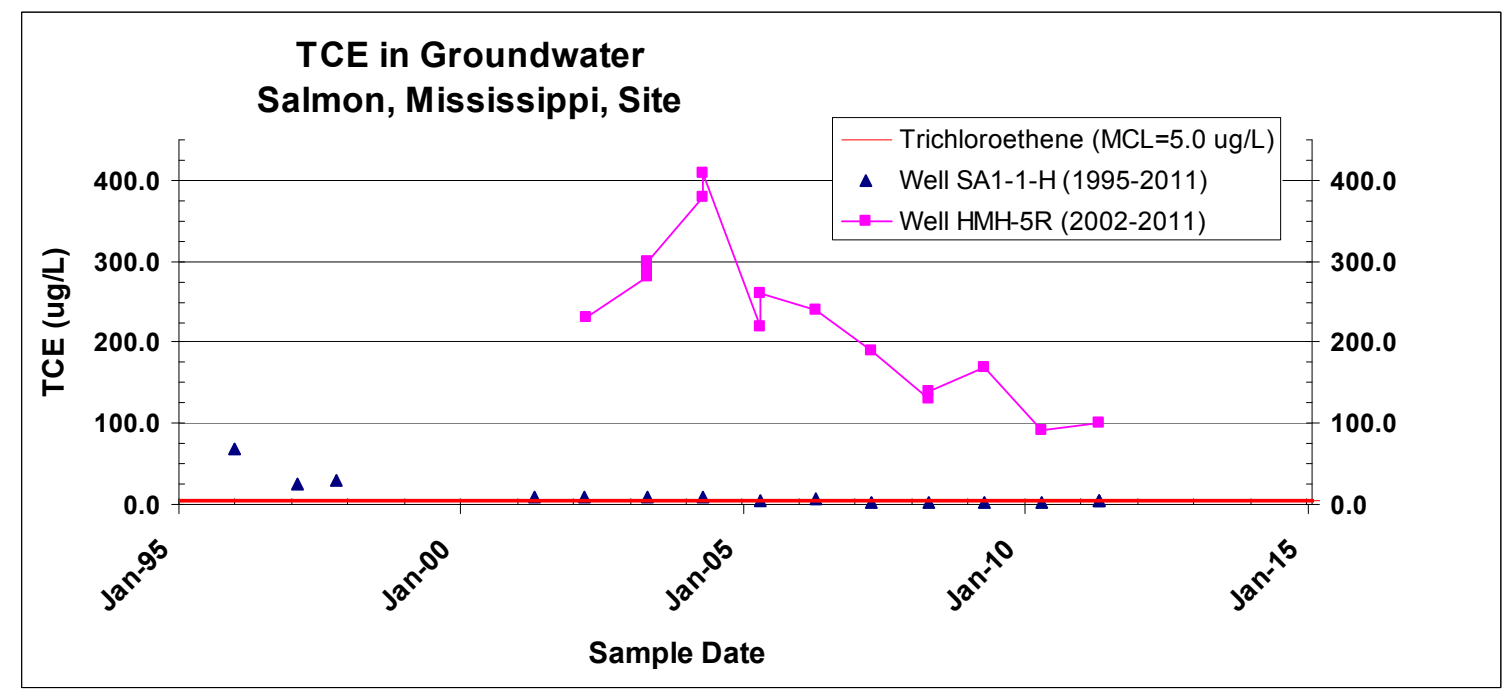

Figure C-14. Trichloroethene (TCE) detected in groundwater since 1995. Only data that have exceeded the MCL at least once during the period are plotted. 


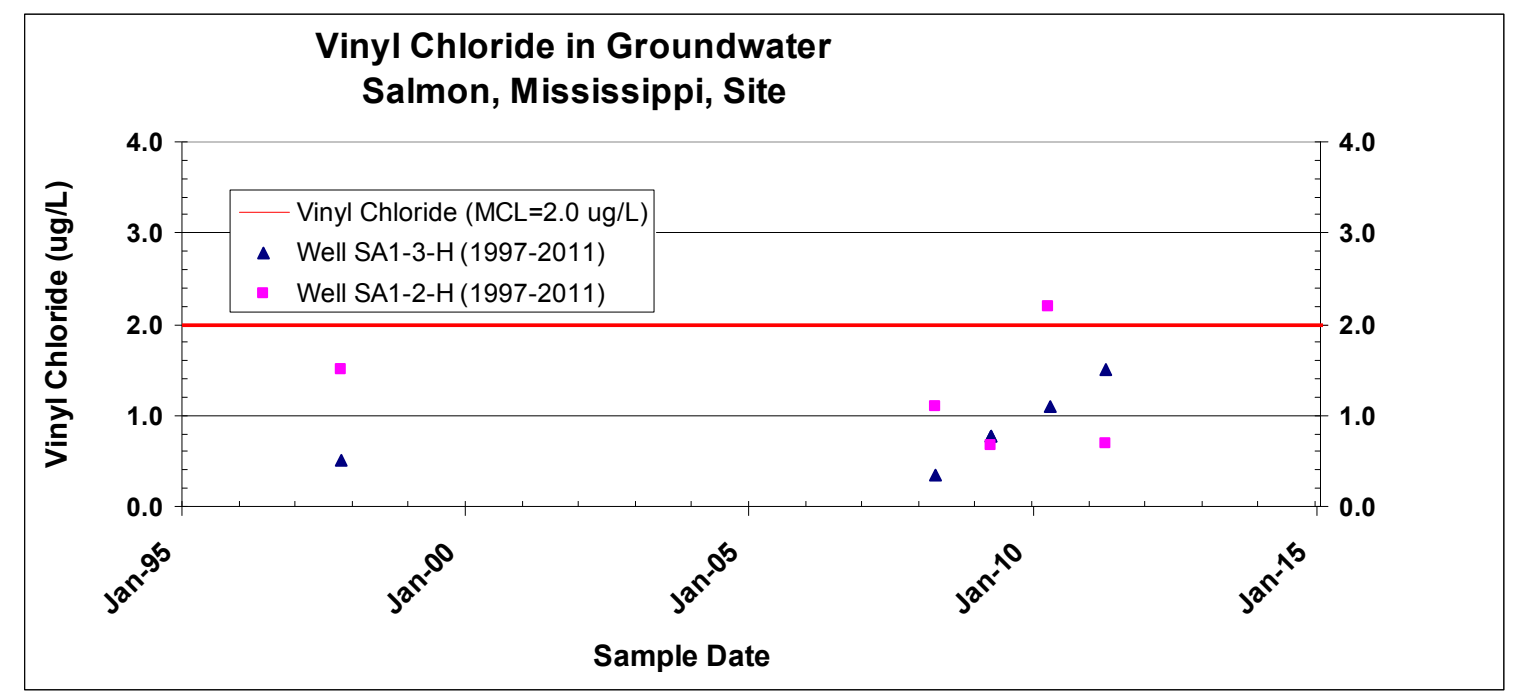

Figure C-15. Vinyl chloride detected in groundwater in two wells since 1997. The concentration trend in well SA1-3-H is increasing concentration with time since 2008.

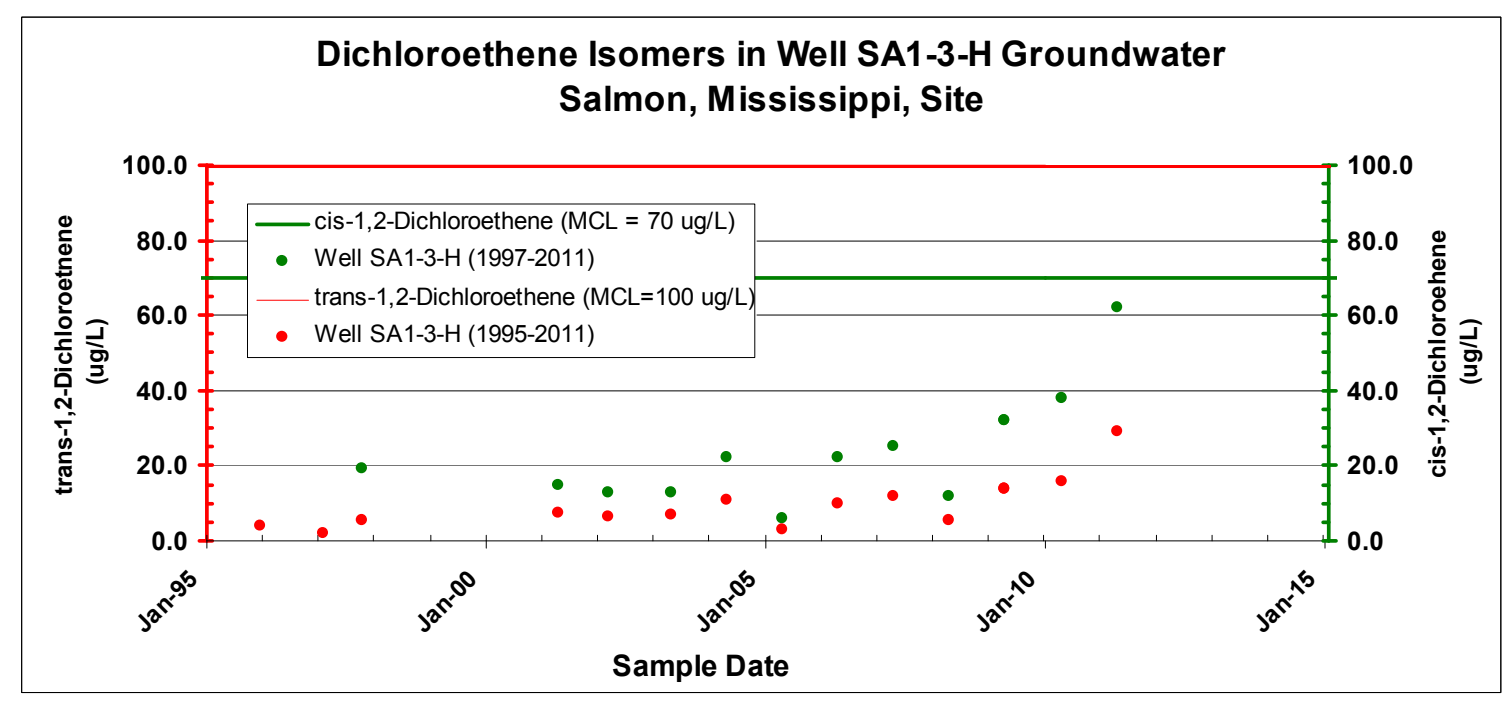

Figure C-16. Isomers of dichloroethene detected in well SA1-3-H since 1995. The concentration trends are increasing with time since 2008. 
Appendix D

\section{Water-Level Elevations}


This page intentionally left blank 
Table D-1. 2011 Quarterly Water-Level Elevations (feet above mean sea level) Tabulated by Well and the Aquifer Monitored

\begin{tabular}{|c|c|c|c|c|c|}
\hline \multirow{3}{*}{ Aquifer } & \multirow{3}{*}{ Well } & \multicolumn{4}{|c|}{ Measurement Period (Date) } \\
\hline & & Q1 & Q2 & Q3 & Q4 \\
\hline & & $(1 / 7 / 2011)$ & $(4 / 21 / 2011)$ & $(8 / 10 / 2011)$ & $(10 / 7 / 2011)$ \\
\hline Alluvial & $\mathrm{HMH}-16 \mathrm{R}$ & 233.2 & 234.9 & 231.3 & 232.0 \\
\hline Alluvial & $\mathrm{HMH}-5 \mathrm{R}$ & 234.6 & 233.2 & 231.1 & 233.4 \\
\hline Alluvial & HM-S & 235.5 & 234.6 & 232.3 & 234.8 \\
\hline Alluvial & SA1-1-H & 235.2 & 234.1 & 231.9 & 234.2 \\
\hline Alluvial & SA1-2-H & 235.2 & 234.3 & 232.1 & 234.5 \\
\hline Alluvial & SA1-3-H & 235.4 & 234.4 & 232.3 & 234.6 \\
\hline Alluvial & SA1-4-H & 236.1 & 235.0 & 232.7 & 235.5 \\
\hline Alluvial & SA1-5-H & 236.2 & 235.2 & 232.7 & 235.3 \\
\hline Alluvial & SA1-6-H & 236.6 & 235.2 & 232.8 & 235.4 \\
\hline Alluvial & SA1-7-H & 236.7 & 235.6 & 233.2 & 235.8 \\
\hline Alluvial & SA1-12-H & 231.6 & 232.9 & 228.9 & 231.7 \\
\hline Alluvial & SA3-4-H & 236.3 & 235.9 & 233.4 & 235.9 \\
\hline Local & HM-L & NA & 152.7 & 152.3 & NA \\
\hline Local & HM-L2 & NA & 155.7 & 154.8 & NA \\
\hline Local & SA1-8-L & $\mathrm{NA}$ & 156.9 & NA & NA \\
\hline Local & SA2-1-L & 157.6 & 157.1 & 156.4 & 156.7 \\
\hline Local & SA2-2-L & $\mathrm{NA}$ & 157.1 & NA & $\mathrm{NA}$ \\
\hline Local & SA2-4-L & NA & 157.4 & NA & NA \\
\hline Local & SA4-5-L & NA & 155.1 & NA & NA \\
\hline 1 & $\mathrm{HM}-1$ & 146.4 & 146.5 & 146.0 & 146.0 \\
\hline 2 & $\mathrm{HM}-2 \mathrm{~A}$ & 127.8 & 128.0 & 126.8 & 127.1 \\
\hline 2 & $\mathrm{HM}-2 \mathrm{~B}$ & 118.7 & 118.9 & 118.2 & 118.5 \\
\hline 3 & $\mathrm{HM}-3$ & 120.6 & 120.7 & 120.1 & 119.9 \\
\hline 3 & SA1-11-3 & 118.2 & 118.4 & 117.7 & 117.7 \\
\hline 3 & SA3-11-3 & 117.2 & 117.4 & 116.8 & 121.1 \\
\hline 4 & SA5-4-4 & NA & 135.2 & NA & NA \\
\hline 4 & SA5-5-4 & 137.4 & 137.1 & 136.6 & 136.3 \\
\hline Caprock & $\mathrm{E}-7$ & NA & 120.3 & NA & NA \\
\hline
\end{tabular}

Quarter (Q) during which the water-level measurements were made:
Q1, Q3, Q4
by Mississippi Department of Health Radiologic Health Division
Q2
by DOE Office of Legacy Management
NA
no value 


\section{Hydrograph Panel for Alluvial Aquifer Wells}

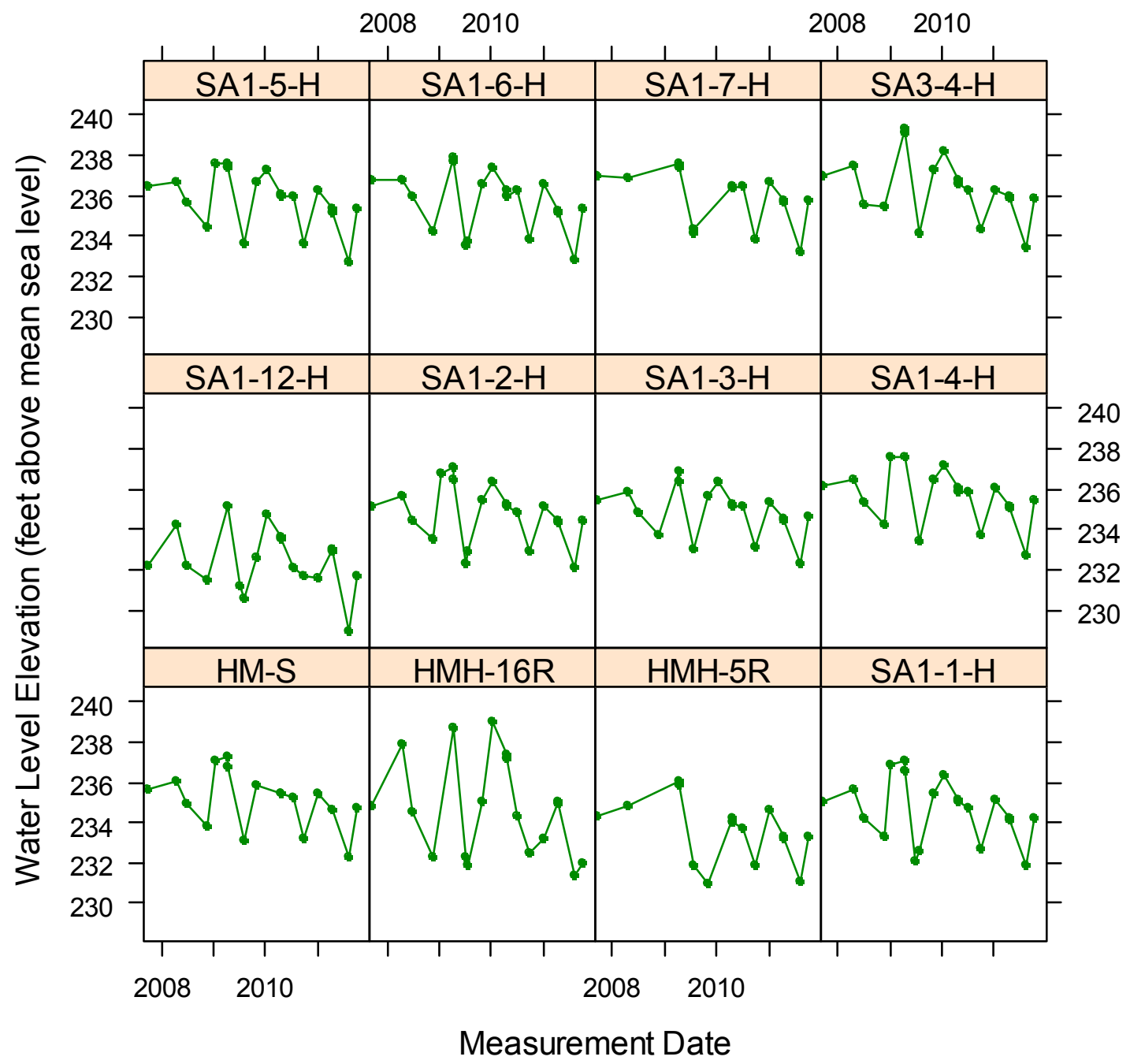

Figure D-1. Plot of hydraulic water head in wells screened across the Alluvial Aquifer versus quarterly measurement date. There are twelve wells in the Alluvial Aquifer: most are clustered around ground zero. 


\section{Hydrograph Panel for Local Aquifer Wells}

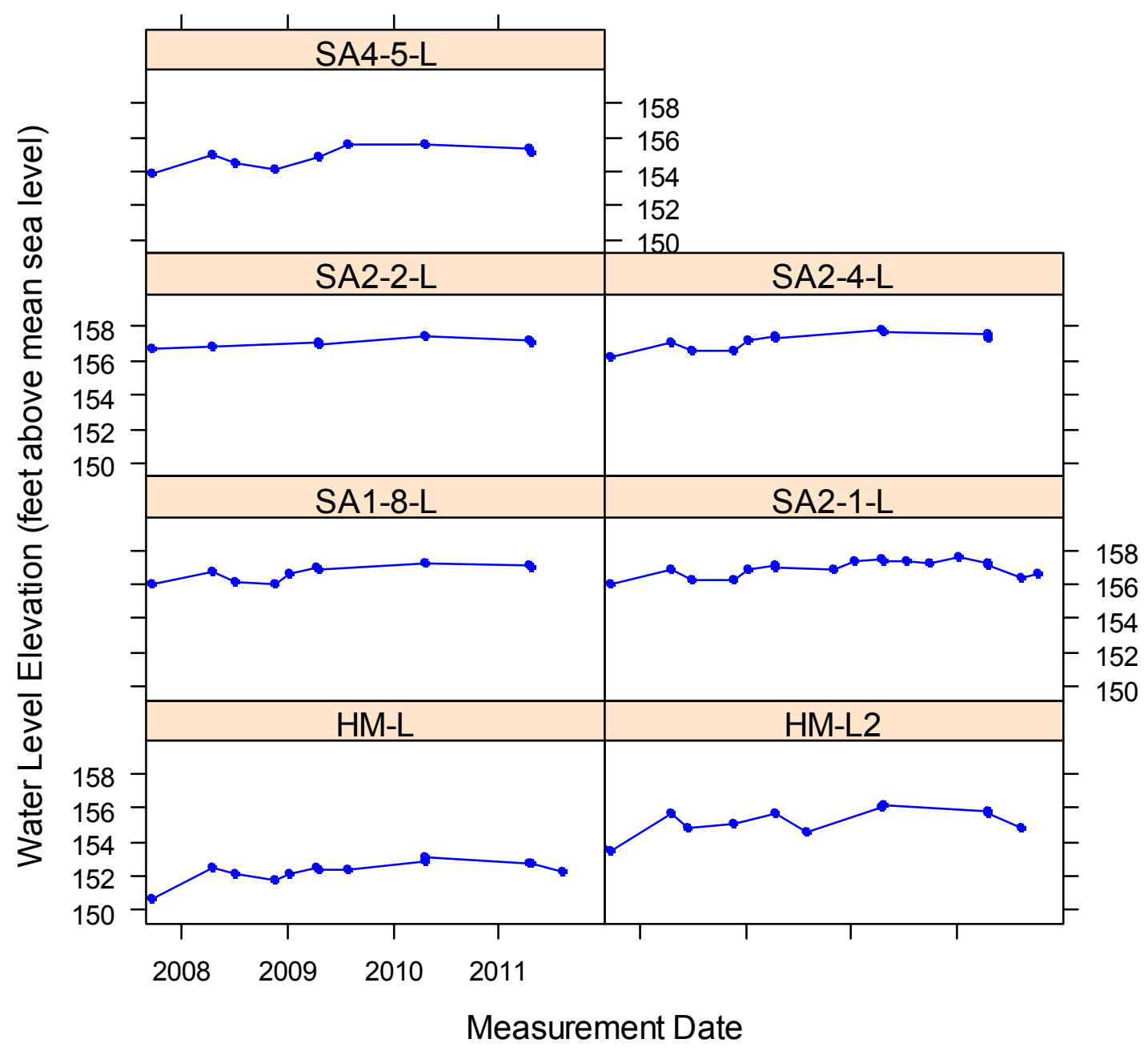

Figure D-2. Plot of hydraulic water head in wells screened across the Local Aquifer versus quarterly measurement date. There are seven wells in the Local Aquifer: one is at ground zero (HM-L), the other six are on highlands that surround ground zero. 


\section{Hydrograph Panel for Aquifer 3 Wells}

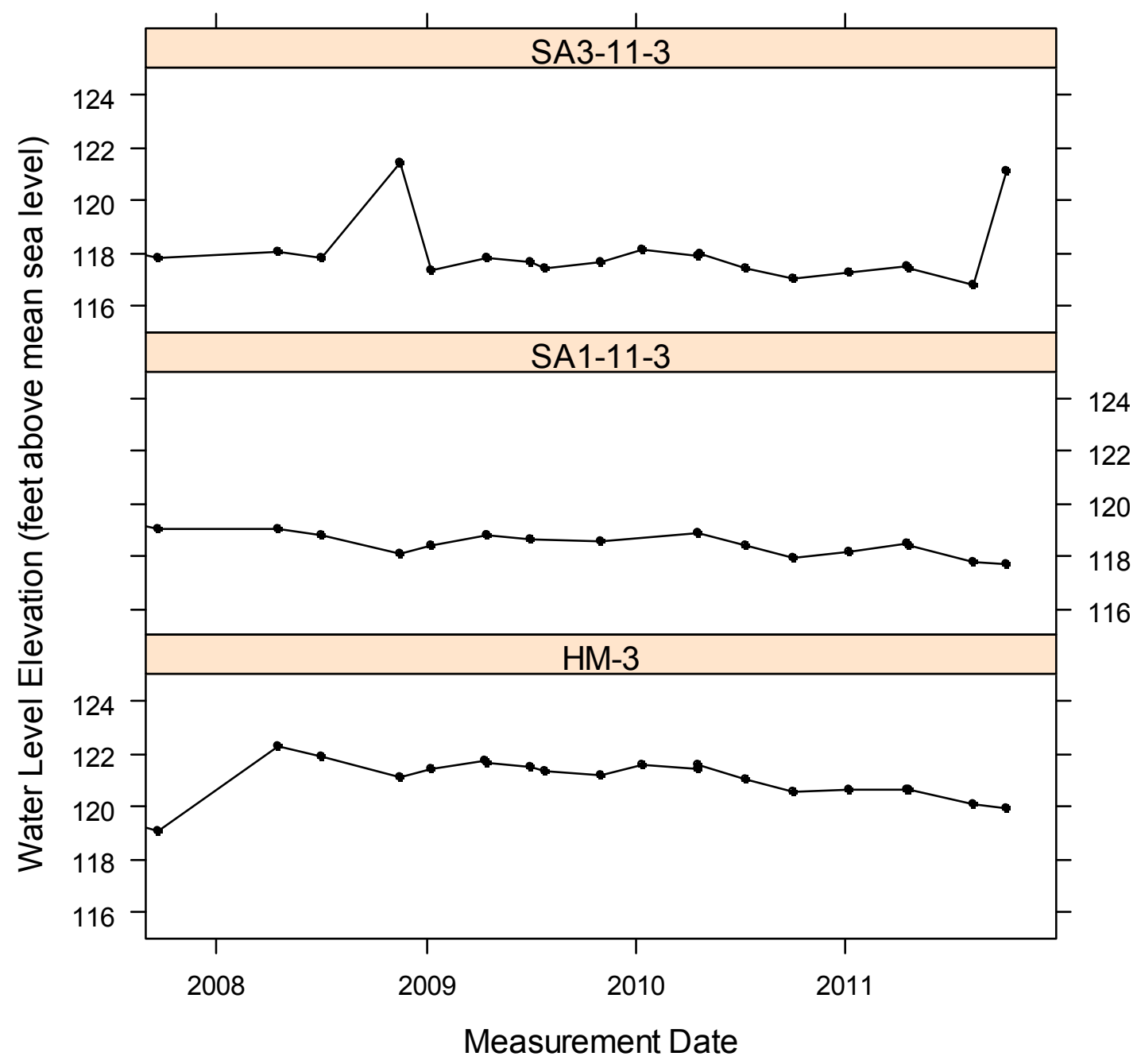

Figure D-3. Plot of hydraulic water head in wells screened across the Aquifer 3 versus quarterly measurement date. Well HM-L is located at ground zero; the other two wells are south and southeast of ground zero. 


\section{Distribution List}

Board of Supervisors

Lamar County Mississippi

ATTN: Tara Coggins

Post Office Box 1240

144 Shelby Speights Drive

Purvis, MS 39475

tlcoggins@lamarcounty.com

Librarian

Purvis Public Library

Post Office Box 289

122 Shelby Speights Drive

Purvis, MS 39475-0289

dfite@lamar.lib.ms.us

Mississippi Department of Environmental Quality

OPC/Groundwater Assessment \& Remediation

ATTN: Bob Merrill

Post Office Box 2261

Jackson, MS 39225

bob_merrill@deq.state.ms.us

Mississippi Department of Health

Office of Health Protection

ATTN: Jim Craig

Post Office Box 1700

Jackson, MS 39215-1700

jcraig@msdh.state.ms.us

Mississippi Department of Health

Radiological Health Division

ATTN: Karl Barber

3150 Lawson Street

Jackson, MS 39213

kbarber@msdh.state.ms.us

Mississippi Forestry Commission

Assistant State Forester

ATTN: Wayne Tucker

600 North Street, Suite 300

Jackson, MS 39202

wtucker@mfc.state.ms.us

Mississippi Forestry Commission

Service Forester - Lamar

ATTN: Kevin Saul

Post Office Box 241

216 Shelby Street

Purvis, MS 39475

ksaul@mfc.state.ms.us 
Mississippi Secretary of State's Office

Public Lands Division

ATTN: Gerald McWhorter

Post Office Box 136

Jackson, MS 39205-0136

gerald.mcwhorter@sos.ms.gov

Southern Nevada Public Reading Facility

c/o Nuclear Testing Archive

Post Office box 908521-8521

Las Vegas, NV 89193-8518

U.S. Department of Energy

National Nuclear Security Administration

Nevada Site Office

Technical Library

Post Office box 98518, M/S505

Las Vegas, NV 89193-8518

U.S. Department of Energy

Office of Legacy Management

Grand Junction Office

2597 Legacy Way

Grand Junction, CO 81503-1789

U.S. Department of Energy

Office of Scientific and Technical Information

Post Office Box 62

Oak Ridge, TN 37831-0062

Phone: 865.576 .8401

Fax: 865.576.5728

reports@adonis.osti.gov

Available electronically at

http://www.Im.doe.gov/salmon/Sites.aspx

Available for sale to the public from:

U.S. Department of Commerce

National Technical Information Service

5301 Shawnee Road

Alexandria, VA 22312

Telephone: 800.553 .6847

Fax: 703.605.6900

orders@ntis.gov

Online Ordering: http://www.ntis.gov/help/ordermethods.aspx 